\title{
BECOMING INSPIRED
}

The (Pre-) Kierkegaardian Author of "Paradise Regain'd"

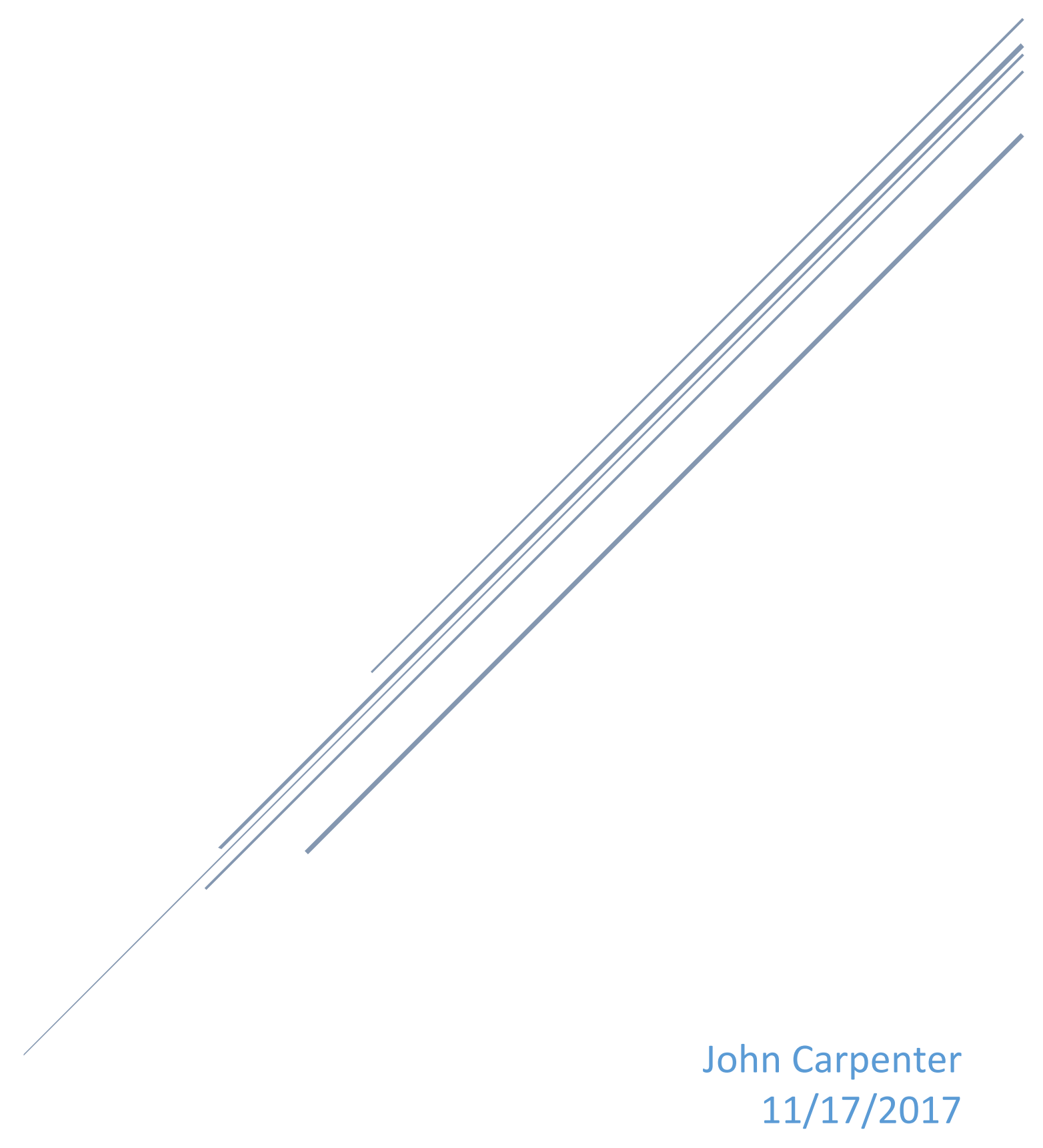




\section{Introduction}

It is no surprise that only a few scholars have tried to pull together a joint study of Søren Kierkegaard and John Milton. In fact, it might come as a surprise that there have been any such studies at all, considering the two-hundred and some years between their lives, the lack of evidence that Kierkegaard knew anything about John Milton, and all the added differences in language, culture, station, and the like. But historicity is not everything, and studies using Søren Kierkegaard's work to read and interpret John Milton’s epic poetry do exist. Why? Because while the roots and branches of Milton and Kierkegaard's biographies never touched, they spent remarkably parallel lives digging into Scripture and reaching for Classical heights—something that, some have found, led them to cast very similar shadows.

Among the first to connect Søren Kierkegaard and John Milton was John S. Tanner. His award-winning book, Anxiety in Eden: A Kierkegaardian Reading of Paradise Lost, is perhaps the only book-length incorporation of a Kierkegaardian concept into Milton criticism. ${ }^{1}$ Not coincidentally, it is also the most successful. Other authors have pursued smaller cross-studies of Kierkegaard and Milton, such as Catherine Bates’ essay entitled “No Sin But Irony: Kierkegaard and Milton’s Satan.”2 Bates’ essay, though, which explores Milton and Kierkegaard’s similar characterizations of the concept of irony, is archetypal of most journal-length uses of

Kierkegaard in Milton criticism: insightful, but generally unambitious studies comparing themes for which Milton and Kierkegaard are already independently known. So unlike Tanner’s totally new introduction of Kierkegaard’s “concept of anxiety” into a reading of Paradise Lost, and thus

\footnotetext{
${ }^{1}$ John S. Tanner, Anxiety in Eden: A Kierkegaardian Reading of Paradise Lost (New York, New York: Oxford University Press, 1992).

${ }^{2}$ Catherine Bates, “No Sin But Irony: Kierkegaard and Milton’s Satan,” Literature and Theology 11, $1: 1997$.
} 
into the repertoire of Milton criticism more generally, the typical incorporation of Kierkegaard's work into this arena tends to focus and refine, not add. And as a result, the big questions of Milton studies persist largely unchanged.

There is one intriguing element of Milton's epic poetry, however, that deserves another treatment like Tanner's—an element that only Søren Kierkegaard's writings can help to make sense of. What is it? The key to that answer is buried in Paradise Regained. Paradise Regained offers a glance into one of the primary focal points where John Milton’s and Søren Kierkegaard's crisscrossing thematic threads meet: their methods of writing about what Kierkegaard calls "Christian silence." ${ }^{3}$ Far from being another thematic coincidence, though, the similarity of Kierkegaard's and Milton's themes of "silence” turns quickly into a renewed exploration of John Milton’s mysterious muse, “Thou Spirit," and turns out to be the key to a long-lasting puzzle in Paradise Regained.

At first glance, themes of "silence" and "Thou Spirit" may appear to be joined only coincidentally within John Milton’s Paradise Regained. Few readers have even turned to the poem specifically with inspirational considerations in mind, Sanford Budick’s The Dividing Muse: Images of Sacred Disjunction in Milton's Poetry being a remarkable exception. ${ }^{4}$ Many more readers, as pointed out by Barbara Lewalski as recently as 2013, are much less sure of what to do with Milton’s “muses” even generally, perhaps because of public statements given by Milton’s family members claiming that Milton himself believed the poetry to have been truly inspired. ${ }^{5}$ Naturally, then, many readers are hesitant to relate these inspirational claims to other

\footnotetext{
${ }^{3}$ Søren Kierkegaard, Christian Discourses, trans. Walter Lowrie (New Jersey: Princeton University Press, 1971), 322. (Abbreviated sometimes as Lilies)

${ }^{4}$ Sanford Budick, The Dividing Muse: Images of Sacred Disjunction in Milton's Poetry (New Haven: Yale University Press, 1985)

${ }^{5}$ Barbara Lewalski, "Milton: The Muses, the Prophets, the Spirit, the Prophetic Poetry,” Milton Studies 54: 2013.
} 
thematic elements of Milton’s poetry. But the “silence” narratively and dramatically central to Paradise Regained, as described by Stanley Fish's landmark reading of the poem, offers an important clue about the irreplaceable role that divine inspiration plays not just in John Milton's poetry, but in his self-understanding as an inspired author. ${ }^{6}$ Fish’s treatment of Milton’s "silence” in Paradise Regained offers a bridge into Søren Kierkegaard’s similar thoughts about “Christian silence,” and if Milton and Kierkegaard’s concepts of Christ “silence” are considered together, then Milton's Paradise Regained can be seen not only as having, but as needing an inspirational source in order to divide and complicate the traditional role of the author.

In other words, the Kierkegaardian silence written into Paradise Regained is not just indirectly expounded there for the reader’s sake, but is actually part of John Milton’s authorial performance of silence-a string in the fabric of Milton's approach to the limits and nature of human understanding. It is no coincidence, then, that another of Sanford Budick's notable books digs into the effects that the reading of Milton’s poetry may have had on the transcendental philosophies of Immanuel Kant. The "Spirit” appealed to at the beginning of Paradise Regained, though often ignored by considerations mistakenly emphasizing the poem’s Christological issues, orients the whole concept of "silence” that runs throughout, and this connection between “silence” and "Thou Spirit” bites into the existential questions Milton had been pursuing for a lifetime: questions of how and what a man can know and understand, certainly, but also how to keep these concerns from bubbling over when the answers are less than obvious.

In effect, then, this thesis is an attempt to connect the transcendental with the existential, the dialectical with the simple, the activity within passivity, and the passivity within activity. But

\footnotetext{
${ }^{6}$ Stanley Fish, “Inaction and Silence: The Reader in Paradise Regained,” in Calm of Mind: Tercentenary Essays on Paradise Regained and Samson Agonistes in Honor of John S. Diekhoff, ed. Joseph Wittreich, Jr. (Cleveland: Press of Case Western Reserve University, 1971).
} 
far from complicating things, Kierkegaard's use of varying levels of reflection, and of the dialectics thus involved in relating these levels of reflection to one another, actually helps to more simply address the difficult and ambiguous questions surrounding Milton's use of and relationship to the muses. Furthermore, Kierkegaard helps to open up the concept of agency working within Milton's inspirational model, unfolding and making sense of Milton's otherwise paradoxical understandings of Christian (in-)action, (silent) speech, and (resignation to) faith.

\section{Outline}

Chapter one provides the primary setting: a gloss on Milton's Paradise Regained and on the traditional readings that it carries in tow, focusing on those readings which emphasize or incorporate the "silence" so described by Stanley Fish. Chapter one also discusses some of the ensuing poetical, philosophical, and theological implications of these readings, finding in these readings a trend toward continually stronger interpretive emphases being placed on Milton's muses.

Chapter two turns to Søren Kierkegaard to work through Lilies of the Field and Birds of the Air, which enunciates the plain workings of Kierkegaard's concept of Christian silence. Understanding Lilies, though, also requires stepping back intermittently to view the book as one small part of Kierkegaard's broader authorship. Finally, the second chapter sets out a three-step view of how Kierkegaard's concept of silence guided and limited the overarching transcendental intentions of his authorship. 
Chapter three addresses the plausibility of translocating a Kierkegaardian understanding of silence into Paradise Regained, parsing out the epistemological and poetical significances of Jesus' silence in Paradise Regained being exhibitive of a Kierkegaardian model of Christian agency. This chapter begins with a discussion of Kierkegaardian "simplicity,” then dives into Milton's use of themes of obedience and resignation in his descriptions of "silence" - themes parallel to those of Kierkegaard's pulled from Lilies in Chapter Two. Milton's famous Sonnet XIX is used to enunciate the relationship between silence, obedience, and resignation in Milton's own work before moving finally into Paradise Regained itself, where Jesus', Mary's, and the Apostle’s resignations are put into a Kierkegaardian perspective. 


\section{Chapter One: The Spirit of Milton}

"There is a "depth," a "profound," the bottom of which cannot be reached by sounding.... Men may speak, may be seen by the operations of their members, may be heard speaking in conversation: but whose thought is penetrated, whose heart seen into? What he is inwardly engaged on, what he is inwardly capable of, what he is inwardly doing or what purposing, what he is inwardly wishing to happen, or not to happen, who shall comprehend?

-St. Augustine of Hippo (Exposition on Psalm 4)

That John Milton's Paradise Regained is a poem primarily about silence, and that this focus on silence can be brought out by close attention to Milton’s subtlest poetic strategies and his broadest theological leanings alike, is an idea best presented in Stanley Fish's landmark essay “Inaction and Silence: The Reader in Paradise Regained.” As the title makes clear, inaction and silence are at the center of Fish’s interpretation of Milton’s second epic, themes that Fish uncovers by tracing two "plots or actions: one narrative or dramatic and the other verbal.”7

On the dramatic level the definition of the relationship between man and God takes the form of a progressive narrowing of the area in which the self is preeminent or even, in a causal sense, active. On the verbal level there is a progressive diminishing, first of the complexity of language and then of its volubility, until finally, as the relationship between God and self is specified, there is only silence.

But if Paradise Regained is a poem about silence, then it also cannot be entirely about silence. First and foremost, for example, it is a poem, and by this simple fact alone Paradise Regained is already subject to a variety of expectations that trouble its purposes. This is a poem about silence, that is, because it is more directly about "the relationship between man and God.” Even where the poem may attempt to develop a reader's understanding of the God-self 
relationship through the narrative and dramatic influences of inaction and silence, the poem is still a story, and so it must begin with scenes and settings that engage a reader via their implications of continuing conflict and narrative development, and then must end with an informative reinterpretation of the relationship between man and God, however inscrutable. On a more basic level, as well, the fact that this is a poem about silence means that it must have been written with words, which are representative of sounds, images, thoughts, and ideas. This presents no insignificant problem for the poet endeavoring to write a piece purportedly, as Fish claims, about silence, because the language of silence, if there is one, operates on a borrowed vocabulary—and it is not a use of this vocabulary that everybody already knows.

In a book probing the integrity of the concept of Christian silence, Diarmaid MacCulloch begins by pointing out how silences so often borrow the entirety of their meanings from contextual relations, such as conflicting intentions or coveted secrets. ${ }^{8}$ But because they are, by nature, the lack of expression (and thus hidden) it is much harder to read these silences for what they are than it might be to read a written sentence. Silences are certainly indicative, and in many cases function in the same way as the written or spoken significances of the language whose contextual meanings they borrow; they require, though, a more discerning eye to initially notice them. It is in this linguistic, but almost invisible sense that Sir Arthur Conan Doyle’s fictional guard dog's silence “spoke,” MacCulloch says, when in its night-time silence Sherlock Holmes found the telling absence that solved the case of the prize stallion:

Gregory: "Is there any other point to which you would wish to draw my attention?"

Holmes: "To the curious incident of the dog in the night-time." Gregory: "The dog did nothing in the night-time."

${ }^{8}$ Diarmaid MacCulloch. Silence: A Christian History. (New York: Penguin Group Inc., 2013). 
Holmes: "That was the curious incident."9

As is typical for the world's most famous detective, it is not really Sherlock Holmes' powers of deductive reasoning that solve the case, but his characteristically ineludible gaze for what others tend to miss. To speak, that is, silences must be noticed, entering the realm of comprehensible awareness, at which point they can be set in relation to ordinary circumstantial subtleties: because the guard dog of Silver Blaze did not bark to alert anybody to the 'intruder,' the perpetrator must not have been an 'intruder' at all; the dog must have been familiar with the murderer/thief who stole the horse. But Sherlock Holmes could only have deduced this veiled insight from what must have simply crossed his mind first: the curious silence of the dog. Without the raw evidence provided by the absence, no deduction would have been possible.

Fish begins “Inaction and Silence,” then, by pointing out how many of Milton’s contemporary critics find issue with his attempt to write a poem in such a way that it, as poetry, cannot never truly be about silence. Fish cites the charges of Russel Fraser, whose argument is that Milton’s tendencies toward "generalization” and “ambiguity” push him away from the use of the so-called "lifeblood of poetry_concreteness and specificity." ${ }^{10}$ On MacCulloch's terms, it is easy to see why Fish might begin with Fraser's anxieties about such a project; "the Platonic impulse, which is also the rationalistic impulse,” Fish says, citing Fraser’s words intermittently, “is grounded in 'a hatred of surfaces' and a corresponding desire ‘to exalt the naked truth’; and in human terms, the category of 'surfaces' includes everything." ${ }^{11}$ Everything, MacCulloch might say, includes silence as well.

\footnotetext{
${ }^{9}$ Collins, Anne, et al. Silver Blaze: and other stories. (Oxford: Macmillan Heinemann ELT, 2005).

10 Fish, 25

11 Ibid
} 
Through the incorporation of anti-Platonic anxieties, though, Fish actually sets Milton’s own projects into their proper context, and seeing how he does this begins to unlock Fish's reading of inaction and silence in Paradise Regained. For example, Fraser's comments have thus far only proven Fish’s starting point: what Fish calls “inaction” is not just at the center of his own interpretation of Paradise Regained, it is the chief complaint of all those disappointed readers who expected it to continue right where Paradise Lost left off. In the borrowed words of his own interlocutors, Fish reminds his readers that in Paradise Regained, "nothing happens,"12 and that fans of Milton's prior work — especially those still enthralled with all the lofty heights and depths explored in Paradise Lost, and who might be excited by the thought of seeing into Heaven and Hell once more-have found in Paradise Regained an unexpected foil. Instead of elaborating on the crucifixion and resurrection of Jesus, for example, Milton details the events leading to the recovery of paradise for mankind within the narrative space bounding the desert temptations, wherein every time the narrative and verbal momentum begins to build anew, Christ, Mary, or the Apostles grind that narrative and verbal movement to a halt. "The pattern of temptation-rejection which constitutes the whole of the poem's plot,” Fish says, "is itself patterned in such a way as to defuse the dramatic thrust it potentially embodies.”13

The situation into which Paradise Regained was written, for Fish, is synchronized almost perfectly with its own narrative and dramatic structure. Just as readers of Paradise Regained end up frustrated with its lack of action, specificity, development, and "human interest" relative to Paradise Lost, we also get in Paradise Regained a relationship between Christ and Satan that feels, at least at first, frustratingly indirect.

${ }^{12}$ Fish, 29

${ }^{13}$ Ibid 
Again and again Satan cranks up a huge amount of machinery which in turn generates an enormous pressure of anticipation-what will the son do? how will he get out of this one? what would I have done in his place?-only to be met (as we are met too) by an evasive and (in terms of expectations the verse has encouraged) inadequate response: "No, thank you"; "I'd rather not"; "With my hunger what hast thou to do"; "Think not but that I know these things; or think I know them not." 14

All of Satan's machinations, built up in the verbal and the narrative movements carried along so fluidly by Milton's poetic flair for extravagance, represent likewise all of the themes and dramas that could have continued straight out of Paradise Lost—-the subsequent arrest of which is not an accident, but, as Fish argues, is part and parcel to Milton's "aesthetic strategy" in Paradise Regained. ${ }^{15}$ The reader that follows along with the inactions and silences of this second epic must learn to identify with the characters in a significantly different way than they might have identified with the characters of Paradise Lost. Though the nature of the character-reader relationship is the same, the pattern is different.

For Fish, the primary difference between the two poems is on one level, narrative or dramatic, and on the other verbal. In Paradise Lost, the "basic pattern of reader-response is one of mistake-correction-instruction," ${ }^{16}$ while in Paradise Regained the reader does not struggle with characters to the point of a culminating insight, but struggles perplexedly against these characters who, in turn, are coming to terms with their own perplexities. The reader-response engagement with the text has become one of "expectation-disappointment-perplexity," so that while the reader is once again mirroring the dilemmas of the characters, the frustrations inherent to that reflective process are of a different nature. Heroic adventure and spiritual discovery in a text full of narrative twists and turns are traded out for a single, ongoing struggle of grappling

\footnotetext{
${ }^{14}$ Ibid

${ }^{15}$ Fish, 26

${ }^{16}$ Fish, 30
} 
with a text that continually reaches less-than-satisfying resolutions_-resolutions which seem, in fact, to just be renewals of patience. ${ }^{17}$ The Apostles’ soliloquies provide a prime example:

Alas, from what high hope to what relapse Unlook'd for are we fall'n! Our eyes beheld Messiah certainly now come, so long Expected of our Fathers; we have heard His words, his wisdom full of grace and truth; Now, now, for sure, deliverance is at hand The Kingdom shall to Israel be restor'd: Thus we rejoic'd, but soon our joy is turn'd Into perplexity and new amaze:

For whither is he gone, what accident
Hath rapt him from us? will he now retire After appearance, and again prolong Our expectation? God of Israel, Send thy Messiah forth, the time is come; Behold the Kings of th'Earth how they oppress Thy chosen, to what height thir pow'r unjust They have exalted, and behind them cast All fear of thee; arise and vindicate Thy Glory, free thy people from thir yoke! But let us wait ... ${ }^{18}$

In other words, the difference that Fish points out between Paradise Lost and Paradise Regained is that the intellectual demands of fresh insight expected in the latter, especially after the psychologically penetrating work of the former, are never actually supplied. Nothing happens explicitly within the poem that makes the Apostles decide turn their attention away from the earthly oppressions that they are so deeply concerned with. After uttering their complaints, both internally to themselves and aloud to one another, and after trying (and failing) to find Jesus out there in the world, the Apostles' response is a simple "but let us wait."

The perplexing feature of this "let us wait," a token statement by the type of which Fish orients his whole reading of Paradise Regained, is the way in which Andrew and Simon inexplicably find comfort in a surcease of anxiety resolvable to no visible change in situation. We begin to see, then, how Fish might go on to separate his reading of Milton's poetic forms from Fraser's, or even to separate his understanding of Milton's concept of silence from that of

\footnotetext{
${ }^{17}$ Fish, 30

${ }^{18}$ John Milton. Paradise Lost: And, Paradise Regained. (New York, New York: Signet Classic, 2001) (PR II.30-49, italics mine)
} 
MacCulloch’s. Silence, for Fraser or for MacCulloch, ultimately rebounds back into the familiar linguistic world. But Fish’s reading of Milton’s Paradise Regained looks for a silence of another sort, one that is not barred from linguistic expression because of its entanglement in conflicting intentions, secrecy, or other familiar "human interest," but which either represents (a) an intellectually indefensible escapism from the cognitive force of present situations productive of anxiety and doubt, or (b) the following of an internal prompting to an unexpected conclusion that, though inexplicable and non-narrative, remains cognitively perceptible in a way beyond these apparent limitations. In the latter case, though, whatever might bar the direct expression of Miltonian silence from being clearly and explanatorily declared is not immediately obvious.

Still, there is abundant evidence that silence in Paradise Regained does not represent a flight from intellectual responsibility. Evidence parallel to Milton’s own predicament, here, might be particularly helpful, as the Apostles have actually come to an answer not unlike that to which Milton comes in his poem "When I Consider How My Light is Spent.”19 In a short, fourteen-line lamentation of his loss of sight, fraught with worries about his inability, as blind, to undertake the worldly work that he believes a disciple of Christ is called to do, Milton earnestly pleads his own case: “Doth God exact day-labor, light denied?” To which the famous response is: “Thousands at his bidding speed/ And post o'er land and ocean without rest/ They also serve who only stand and wait.”

Like Milton, the Apostles offer little justification for their decision to be comforted against present and abounding worries by simply waiting. The decision presents an evasion of responsibility, either for action or for explanation, which, considering Peter C. Herman’s work

\footnotetext{
19 John Milton. Milton's selected poetry and prose: authoritative texts, biblical sources, criticism. Ed. Jason Philip Rosenblatt. (New York: W.W. Norton \& Co., 2011).
} 
on poetic incertitude, looks remarkably like a cognitive “gap.” ${ }^{20}$ As Fish comments, "by omitting any transition between the anguished voicing of genuine needs and the unexpectedly sudden gesture of resignation, the poet calls attention to the perversity (in human terms) of his characters’ non-response.”21 But the narrative form of Milton’s own poetic negotiations with the Apostles’ predicament pushes back against an interpretation of these lines that garners from it solely this cognitive dissonance. Instead, we find that Milton not only willingly pursued the anxiety-producing line of thought that led him to question his own existential fate, but that he also found, somewhere in his "non-response,” an existential comfort that is utterly unexpected from the outside looking in.

The pattern of expectation-disappointment-perplexity in Fish’s reading of Paradise Regained, then, is not just a broad narrative recurrence, but instead can be considered as the necessary relationship between two intermingling narratives built into the poetic structure of the text simultaneously. Ultimately, this is the key to Stanley Fish's paradigmatic "reader-response" modeling of the text: it allows for multiple avenues of narrative movement through Paradise Regained, avenues differentiated from one another by an epistemic gap between two modes of understanding (and thus of living in the world) that cannot be directly bridged. The reader is set up to enter the text on what Fish calls "human terms," whether that entrance is because of a prior reading of Paradise Lost or because of Milton's use of Satan's machinations to produce the same result. The reader's expectation of a story that makes sense on the human terms of action and explanation, then, stand against a story that apparently develops in terms of inaction and silence, and because of this narrative standing, Fish's Milton presents inaction and silence to the reader in

\footnotetext{
${ }^{20}$ Peter C. Herman, Destabilizing Milton: Paradise Lost and the Poetics of Incertitude (New York: Palgrave MacMillan, 2005).

${ }^{21}$ Fish, 32
} 
the negative; it is only discoverable for the reader interrogating internally, as in the model of the disciples, their own readerly “expectations,” and through them also the “disappointment” and “perplexity” to which they are causally tied. To identify and associate with the renewal of patience and the ensuing comfort, the reader must learn how to traverse what is in the poem traversed non-narratively_ and thus, in a narrative sense, invisibly. The problem, then, is simply: how? What else but “human terms”? How does Milton’s aesthetic strategy of eschewing “particulars” become “a vehicle for raising the reader's mind to the point where reality discloses itself?"22

If Milton's aesthetic strategy is to be considered as successful in any sense of the word, then a real answer to these questions must be hidden within the indirect addresses to the intellectual or moral demands generated by the non-actions of Jesus, Mary, and the Apostles. Conveniently, the best evidence that Milton’s silences indicate the presence of an aesthetic strategy based on indirect communication is actually the most obvious, plain-sense reading already present at the very beginning of Paradise Regained; by the end of the second sentence, Milton is making curious and somewhat contradictory claims about the story to come:

I Who e're while the happy Garden sung, By one mans disobedience lost, now sing Recover'd Paradise to all mankind, By one mans firm obedience fully tri'd Through all temptation, and the Tempter foil'd In all his wiles, defeated and repuls't, And Eden rais'd in the wast Wilderness. Thou Spirit who led'st this glorious Eremite Into the Desert, his Victorious Field Against the Spiritual Foe, and brought'st him thence
By proof th'undoubted Son of God, inspire, As thou art wont, my prompted Song, else mute, And bear through height or depth of nature's bounds With prosperous wing full summ'd to tell of deeds

Above Heroic, though in secret done, And unrecorded left through many an Age, Worthy t'have not remain'd so long unsung. ${ }^{23}$

${ }^{22}$ Fish, 26

${ }^{23}$ PR I.1-17 
Perhaps the only thing that Milton indicates directly at the beginning of Paradise Regained is that he is writing of the earthly life and victory of Jesus. As soon as Milton begins to call upon the "Spirit" to "inspire...my prompted Song" in the second sentence, his claims and purposes become less straightforward. Among these pivotal, indirect points that generate perplexity and draw the reader's confused attention occurs in line 15, where Milton describes Jesus' victorious deeds as "in secret done," “unrecorded,” and "long unsung.” It is unclear here to what "Above Heroic” deeds Milton is referring, that is, because the series of events unfolding in Paradise Regained are the familiar desert temptations, and have been depicted in the gospels of both Matthew and Luke. This story is not "unrecorded"-it has been recorded twice in the gospels alone and repeated innumerably in the centuries (and millennia) since.

In The Dividing Muse: Images of Sacred Disjunction in Milton's Poetry, Sanford Budick suggests that with the opening lines, Milton is expressing his aspiration "to recover from the known events of paradise regained, new, secret, meanings that heretofore have not been understood. He will attempt, in other words, to discover in the known written record new definitions of the theological terms that we may have thought were already fully explicated.”24 Budick's interpretation grants a certain degree of wiggle-room within the problem that Milton's counter-intuitive claims toward ingenuity present. Budick also qualifies Fish’s reading of Paradise Regained, claiming that "while silence is one of the key effects achieved by the poem, it is, I believe, only one component in the fully formed language of Christian experience that Milton is attempting to recreate." ${ }^{25}$ As Budick's own title suggests, he finds the link between the

\footnotetext{
${ }^{24}$ Budick, 123
}

${ }^{25}$ Ibid, 124 
Muse and Milton's cognitive disjunctions to be equally central for an adequate understanding Milton’s poetic strategies.

Budick’s interpretation might need a small adjustment, though, to account for the dimension of Milton's purpose exposited by the use of the word “deeds” to describe Jesus' socalled “unrecorded” victory. Interestingly enough, that dimension brings activity, and thus brings Fish’s focus on silence, back to the forefront of Budick’s “language of Christian experience.” Something unaccounted for must have been performed, that is - no amount of theological misinterpretation or misrepresentation of the Gospels would mean, at least on Milton’s terms, that the "above Heroic” “deeds” actually recorded in the desert narratives would in fact become thus “unrecorded.” This simply cannot be the case of a story recorded in the scriptures, as for Milton, the purity of the scriptures is spiritually indelible. He says as much through the mouth of the angel Michael, in one of the final sending-off speeches of Paradise Lost:

\section{At length,}

Their [the Apostles'] ministry performed and race well run, Their doctrine and their story written left, They die, but in their room, as they forewarn, Wolves shall succeed for teachers, grievous wolves Who all the sacred mysteries of Heav'n To their own vile advantages shall turn Of lucre and ambition and the truth With superstitions and traditions taint, Left only in those written records pure Though not but by the Spirit understood. ${ }^{26}$

Something happened, according to Milton, which is simply not written about in the Gospels of Matthew and Luke. But at the very same time, those unwritten “deeds” must also have been hidden there within the Gospels. Michael's speech in Paradise Lost does not annul Budick’s interpretation that the unrecorded, “unsung” elements within Paradise Regained are in one sense

${ }^{26}$ PL, XII.504-514. (italics mine) 
new definitions of familiar theological concepts. Instead, Michael's speech simply offers accommodating space to push that interpretation a little further, by including Milton's use of “deeds" as a description of what had been previously unrecorded in the gospel stories.

When Budick claims that what Milton newly records in Paradise Regained is "the christening of the Christ-like elements of human awareness that make in an inward paradise available 'to all mankind,"” and that "the key to the realization of Milton's objectives is his unfolding or further revelation of the hidden valences of revealed language," ${ }^{27}$ Budick is on the verge of recognizing the hidden volitional valences inherent within what he dubs the "Christ-like elements of human awareness.” This addition would satisfy a need to recognize Milton's use of “deeds," which implies that there were willful actions in the desert that went "unrecorded,” by situating the very notion of Christian action itself within a space markedly internal. Such an understanding of spiritual action would not refer to the bodily or verbal movements of Jesus in the desert that had previously been recorded, but to those actions that occur subtly within the empty narrative space now newly exposed by Milton through his use of the emphasized poetic disjunctions at play throughout the text. At the very least, uniting Budick’s and Fish’s interpretations of Paradise Regained makes considering Jesus' silence as a kind of expressive activity, of which there are certain types of unrecorded “deeds,” possible.

Urging the reader to treat basic features of human awareness as a realm of expressive activity within which Jesus acts or refuses to act (if that is really what Milton is up to) does not just use, but also deepens the claims made by Fish’s "Inaction and Silence” as well. The inclusion of a volitional valence appears at first to be a confusion of Fish's claim, who argues

${ }^{27}$ Budick, 124 
that volition in Paradise Regained is disappearing. Fish has already included a volitional valence into what should simply be a matter of choosing to let go of that volition, which alleviates the ongoing processes of perception and misperception, expectation and perplexity, correction and reinterpretation—-processes which, as silenced, make of Milton’s non-narrative an explicable and understandable practice of agential abnegation. Obedience is, as Fish says, a process of the continuous deepening of a single insight "that is never superseded.”28

Fish’s single biggest oversight regarding Paradise Regained, then, which Budick manages to catch, is that the notion of divine inspiration implies a division of the authorial self that complicates what would otherwise be rather simple dynamics of agential abnegation. Agential resignation that yet produces action-“deeds,” we might say, of which resignation itself is a type-is the form of a kind of relationship between not one, but two or more types of agency at play within the inner sanctum of perceptual activity. Fish's silence does perhaps involve another agent, if we consider as an agent "God’s will,” which Fish only wraps into his interpretation of Christ's actions in Paradise Regained at the pinnacle moment. But regarding that 'who' or 'what' which supplies the spiritual impetuses responsible for actions that are irreducible to the will of the narrative actors themselves, Fish silently relies on nothing more than unreferenced, plain-sense understandings of Milton’s own claims, such as in the passage following:

So they in Heav'n their Odes and Vigils tun'd: Mean while the Son of God, who yet some days Lodg'd in Bethabara where John baptiz'd, Musing and much revolving in his brest, How best the mighty work he might begin Of Saviour to mankind, and which way first Publish his God-like office now mature,

\footnotetext{
${ }^{28}$ Fish, 28
} 
One day forth walk'd alone, the Spirit leading;

And his deep thoughts, the better to converse

With solitude, till far from track of men,

Thought following thought, and step by step led on,

He entred now the bordering Desert wild,

And with dark shades and rocks environ'd round,

His holy Meditations thus persu'd. ${ }^{29}$

On Fish's terms, a binary of personal intentions and God's will, we ought to see Jesus acting either on God's promptings alone, on his own volition, or, (and only where they are one and the same) both; the passage above, however, describes a situation in which two volitional valences inherent to Milton's telling of Paradise Regained, the Spirit's leadings and Jesus’ own intentionalities, are not only simultaneously present in Jesus’ actions, but are present together separately, in the development of two distinct, but entangled narrative images occurring simultaneously. Of yet, this division of the agential self has not set the claims being made here apart from Fish's, but implies that they must be said in another way-and that makes all the difference. For if it is the case that such a paradoxical inner expression of two wills in one action (even the action, that is, of walking out into the desert) requires an agential presence markedly outside one's own control to synchronize with or to channel, which for Fish would simply be “God’s will,” Budick calls us to recognize how, considering Milton’s aesthetic strategies, “God’s will” should actually be described as "Thou Spirit” (the muse to which Milton attributes the previously unrevealed elements of Paradise Regained), which carries implications.

Michael's slight ambiguity of speech about the Spirit in Paradise Lost, and his words on scripture as “though not but by the Spirit understood," contains multiple interpretive possibilities for Paradise Regained that, united, provide an indication that Milton envisioned a complicated

${ }^{29}$ PR, I.182-195 (italics mine) 
agential picture within his own writing process. For on one hand, Michael's words about the purity of scripture "though not but by the Spirit understood" can be interpreted to mean that the Spirit is the only being that can, in a self-sufficient sense, purely understand the scriptures. Directly, this locks out pure and full human interpretation of the scriptures as a possibility. For humanity, that is, some of the truths of the scriptures are simply and inevitably incomprehensible. But on the other hand, Michael's line can also begin to pry at that same lock indirectly, if his words are read to mean that only by mutual labor with the Spirit, or by reading the scriptures through the Spirit, can they be purely understood-that is, that an understanding is possible, even one without taint, by working with the Spirit directly. This latter reading seems to be Milton's, as well, for in Paradise Regained Jesus says to Satan that:

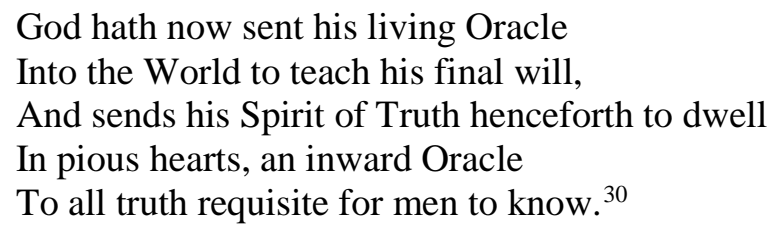

The two possible interpretations of "though not but by the Spirit understood," taken together, reify Milton’s barring of human understanding from the depth of purity required to understand all that lies within the hiddenness of scriptural language, but they also point toward a possibility for an agential cooperation in which human understanding seeks to sync itself to and model itself after the guiding Spirit, or “inward Oracle,” by the process of giving jurisdiction over the breadth and exercise of one’s agency and understanding up to it. In the beginning of Paradise Lost, the invocation of the Spirit has clear indications of such a meaning:

${ }^{30} \mathrm{PR}, \mathrm{I} .460-464$ 
Of Man's first disobedience and the fruit Of that forbidden tree whose mortal taste Brought death into the world and all our woe With loss of Eden till one greater Man

Restore us and regain the blissful seat Sing Heav'nly Muse, that on the secret top of Oreb or of Sinai didst inspire

That shepherd who first taught the chosen seed, In the beginning, how the heav'ns and earth Rose out of Chaos. Or if Sion hill Delight thee more and Siloa's brook That flowed fast by the oracle of God, I thence Invoke thy aid to my advent'rous song That with no middle flight intents to soar Above th'Aonian mount while it pursues Things unattempted yet in prose or rhyme. And chiefly thou, O Spirit, that does prefer Before all temples th'upright heart and pure Instruct me, for thou know'st, thou from the first Wast present and with mighty wings outspread Dove-like sat'st brooding on the vast abyss And mad'st it pregnant. What in me is dark Illumine, what is low raise and support, That to the height of this great argument I may assert Eternal Providence And justify the ways of God to men. ${ }^{31}$ 
While the Heavenly Muse directs and aids Milton where external historical events are concerned, and the Spirit, who "from the first wast present and...dove-like sat'st brooding on the vast abyss" can there provide additional support, the primary invocation of Spirit refers to that which is internal to Milton. The Spirit is that which instructs, illuminates, raises, and supports what is “dark” and "low," in the description of which we might remember, considering our context as a discussion of silence, how directly the relation is between the "abyss" that the Spirit “mad’st...pregnant” and Milton’s ability to “assert Eternal Providence.” Just as in Fish’s claims about the twin themes of Paradise Regained, the movement from instruction by the Spirit to the assertion of eternal providence is not, as it may appear to be, a movement of consecutive insights as was undertaken in the heavy and broadly theological goings-on of Paradise Lost. Instead, the Spirit of Paradise Regained sits right here, in the space between “O Spirit” and "Eternal Providence,” as a single ratio guiding a movement that is in a worldly sense epistemologically and existentially backwards, a process of un-seeing, un-valuing, or un-instruction-in other words, abyssal—while in a spiritual sense a "purity" that is born out of that abyssal point, and from there moves onward from "abyss” to "pregnant," from "dark” to light, from "low” to high.

This latter portion of the process of reeducation by the Spirit corresponds to the second of the two intertwining narratives Fish finds written into Paradise Regained. Such an inspirational education, however, is no longer educational in a direct sense. It is productive of a form of understanding that is, from the beginning, born out of the negation of the prior understanding, and thus may not necessarily be expressible in the terms of the previous understanding, the attempt at which entails the generation of perplexity (although Jesus’ biting emulation of Satan’s reasoning in Book III suggests that Milton considers the barriers of understanding to be 
unilateral; new understanding can certainly still make sense, and fun, of the old). Rather, such a form of education by continual self-abnegation is by definition unsure of the guiding terms of self-understanding that will come out of that abyssal space created in silence, as that is precisely what has been and is continually being given over into the domain of the Spirit and its “inspiration.”

It is here, however, that we should be careful to note that giving the jurisdiction of the understanding over to the inspiring Spirit does not necessarily mean, for Milton, that in the present sense the self becomes utterly passive and unable to act; we should also note that the givenness of knowledge or insight inherent to the mode of understanding via spiritual inspiration does not imply the utter incomprehensibility of, or the inability to reflect upon, those subsequent understandings. On Fish’s model of expectation-disappointment-perplexity, the passivity (inaction) and incomprehensibility (silence) of Milton's characters appears most palpably to the reader as a dissonance both between his- or herself and the characters, on one hand, and between the characters and themselves (at narrative points $a$ and $b$, that is) on the other. But the true difference between the characters and the reader is the capability with which the characters reconcile themselves to this cognitive dissonance that is felt by character and reader alike.

That the form of navigating the cognitively dissonant space between perplexity and comfort in Paradise Regained is an internal replication of Milton's characters' active obedience can also be dug out of the dialectical creating-and-dissolving activity of imagination perpetuated within Milton’s visual imagery. The process of thought that Milton’s poetic abstractness produces, which has been uncovered by the gaze of one of the longest continuing conversations in Milton Studies to date, is defined by the repeated endeavor to expand and reach beyond what is within our presumed epistemological horizons. "Visual duration in Milton’s Verse,” says 
Budick, "is not imagistic life but imagistic half-life, interminably regenerated, endlessly disintegrated...It is a distinctive way of revealing the world, a different symbolic order.”32 Budick cites an example first used by Coleridge in an analysis of Paradise Lost, along with some of Coleridge's comments on that passage, to expose the "imagistic half-life" he is pointing to:

and daughters grow

About the mother tree, a pillar'd shade

High over-arched, and echoing walks between:

There oft the Indian herdsman, shunning heat, Shelters in cool, and tends his pasturing herds, At loop holes cut through thickest shade. ${ }^{33}$

Then, as Budick discusses Coleridge’s reading: “In Milton’s poetry...'the imagination is called forth, not to produce a distinct form, but a strong working of the mind, still offering what is still repelled, and again creating what is again rejected; the result being what the poet wishes to impress, namely, the substitution of a sublime feeling of the unimaginable for a mere image.”"34 Passages including language such as "loop holes cut through thickest shade," “echoing walks between,” or “a pillar’d shade,” along with familiar phrases such as Milton’s famous "black fire” and "darkness visible," express the unimaginable by way of indirect experience.

But even for Coleridge, the success of a process of linguistic expressions attempting to transcend themselves - that is, to become more than an imagistic sum of their own parts by touching up against the unimaginable "sublime"-requires a kind of internal division, or internal other, that clouds the authorial boundaries within Milton's poetry. Coleridge’s thoughts related to

\footnotetext{
${ }^{32}$ Budick, 7

${ }^{33}$ PR, IX.1105-1110

${ }^{34}$ Budick, 11 (Cited: "Seven Lectures on Shakespeare and Milton by the Late S. T. Coleridge, ed. John Payne Collier (London, 1856),” pp. 64-66; italics mine)
} 
such poetic expression, for example, included a division of the imagination into the generative and the reflective, the "primary" and the "secondary," of which the primary would be "the living Power and prime agent of all human Perception...a repetition in the finite mind of the eternal act of creation in the infinite I AM," while the secondary would be "an echo of the former, coexisting with the conscious will, yet still as identical with the primary in the kind of its agency, and differing only in degree, and in the mode of its operation.”35

Coleridge's division of the authorial self, of course, does not necessarily mimic or replicate Milton’s. His is another interpretation of what, in Milton’s case, were simply the undiscussed internal mechanics necessitated there beneath Milton’s agential and poetic selfunderstandings. But Budick’s insight into this problem is that Milton’s own understanding of the division of agency internal to the silences and inaction of Paradise Regained should, again, be considered within the study of the authorial influences and aid of the Spirit. Budick was early, in this regard; as recently as 2013, Milton Studies published an article by Barbara K. Lewalski calling Milton scholars to attend to the muses, including the Spirit, individually:

We need to attend with greater care to what Milton himself means by casting himself as, in some sense, a prophetic poet. Throughout his long career he refers often, in several works of prose and poetry, to various prophets, to the muse, and to the Spirit. Rather than bundling such references together under the rubric "prophetic," or "visionary," we need to attend to their specificity, to the circumstances and implications of his identification with particular prophetmodels, and to ask when, and why, he now addresses particular muses or the Spirit of God. Doing so reveals that Milton's self-definition as prophet-poet is complex and that from the beginning it coexists with strong assertions of authorial agency. ${ }^{36}$

\footnotetext{
${ }^{35}$ Budick, 10 (Cited: "Samuel Taylor Coleridge, Biographia Literaria, ed. J. Shadowcross, 2 vols. (Oxford: Oxford University Press, 1907), vol. 2, p. 12 and vol. 1, p. 202.)

${ }^{36}$ Lewalski, 60.
} 
The authorial character of many of Milton's muses is limited in the ways Lewalski describes. They often assume the role of an imagistic repository, store-housing imaginative material that Milton draws from and directs at his own imaginative discretion, and which thus remain subject to what Lewalski calls Milton’s “strong assertions of authorial agency.” But because of this typical characterization of the inspirational muses, only very little of Milton's poetic style has been studied as Sanford Budick studied it—attributed, that is, to the muses as authorial figures within Milton that complicate his linguistic and imaginative capabilities. This lack of attention to the Spirit in particular is unfortunately obscuring key elements of Milton's references to the Spirit as a muse in Paradise Regained.

As Lewalski attests, it seems to be the case that the historical Milton took his proclamations of inspiration rather seriously, ${ }^{37}$ which means that Milton’s prophetic selfunderstanding of an influence on his conscious experience by a present Spirit makes an interpretive difference not only for understanding Milton’s poetic universe, but also for understanding how his calls upon that Spirit altered the shape of his writing even as far down the linguistic structures Budick discusses.

His inattention to the muse of the Spirit is, I think, the source of Stanley Fish's slight straying from Milton in "Inaction and Silence.” Fish describes the process of linguistic and active diminishment accurately, but by the aid of what must eventually become an obscuring lens: pure theological acumen and an acute, laser focus on a reader-response model of engagement with Paradise Regained. So Fish still catches the influence that Milton’s guiding Spirit represents linguistically, i.e. that Milton’s poetry “deliberately eschews those very qualities

\footnotetext{
${ }^{37}$ Lewalski, 59
} 
of language that are the lifeblood of poetry-concreteness and specificity." 38 But Fish misses an opportunity to tie this process to the inspiring Spirit as the muse of Paradise Regained, which leads to some problematic theological assumptions.

Fish’s understanding of Milton’s peculiar and self-destructive images is that they are poetic manifestations rooted in what he called, following Russel Fraser’s lead, Milton’s “Platonic impulses.” Platonic impulses, for Fish, make sense of the ways that “it is Milton's insight into the working of poetry, that is, of what it is a symptom, which underlies his aesthetic and dictates his strategy.” "Platonic impulses” might be viewed as another way of representing something about the functioning of Spirit as muse, for Milton, that strips away surface material potentially occluding the underlying reality. But Platonic impulses are not the Spirit, and an attention to the Spirit would make more serious the claim that Milton's “poetry, by working against its own best interests (in a narrow sense), works against that something [that occludes] and so becomes a vehicle for the raising of the reader's mind to the point where reality discloses itself.”39

In Fish’s reading, reality (perhaps Reality) does finally disclose itself to Jesus. As he stands upon the pinnacle after Satan's final temptation, having exclaimed his “Also it is written, tempt not the Lord thy God,” he has become "a new and stronger self, the amalgam I-thou to whose presence the force of the ambiguity" (the ambiguity of which agent had spoken, Jesus or God) "bears witness." ${ }^{40}$ In an abundance of ways, Fish’s reading touches on the correct points of ambiguity that Milton uses to communicate indirectly to his readers. The culmination of Christ's silence is a total synchronization with "God's will” so tight that the two are unified, the Godand-man in one. Christ's words “Tempt not the Lord thy God” are ambiguously spoken as either

\footnotetext{
${ }^{38}$ Fish, 25

${ }^{39}$ Ibid, 26

${ }^{40}$ Ibid, 43
} 
God, Jesus, or both. But Fish trips up against an objection by Arnold Stein that he himself includes to attempt to answer: that "to see this as Christ's 'claim”” (to divinity) “...is to abandon much of the force of the disciplined demonstration—as well as to abandon Milton's own passionate religious and moral belief, and his own disciplined unwillingness to pry into God's maintained mysteries." 41

For Fish, Jesus performs the definitively miraculous for just a moment: “The Son performs the impossible feat of saying silence and makes himself disappear.” But therein lies Fish's dilemma. If it is the case that Jesus' speech and action has sufficiently lacked his own willfulness up to this point, as it presumably has, then this moment is really no different than the rest of the poem. Jesus has talked repeatedly with Satan throughout. He has been obedient to the “Spirit leading," as well, so his will has not changed. God's will toward Jesus should not have fundamentally changed, either, for it is directly at the pinnacle of Jesus' temptations—not after, and thus in response to, Jesus' proving of his full obedience-that God's voice and Christ's narratively collide. All in all, this scene cannot communicate any real theological meaning that is not already and simultaneously more invisibly present throughout the whole poem indirectly. If Jesus here disappears, then Jesus also never was, which means that either: (a) nowhere in the poem is Jesus in the act of silencing, i.e. he is already silent; or (b) Jesus is everywhere in the act of silencing and in the act of silence simultaneously, including the pinnacle moment.

A moment of spontaneous miracle upon the pinnacle can only result in a flawed interpretation, for neither (a) nor (b) cohere with a spontaneously miraculous pinnacle moment. Such interpretational errors, I believe, are built on an over-attentiveness to inaction within the

${ }^{41}$ Ibid 
scope of Jesus' conversations with Satan and under-attentiveness to the ways in which Jesus' actions throughout represent, in so many of the ways that Fish still rightly leads us to, a silence that is an active, obedient, mimetic replication of the Spirit's prompting. As we read through the narrative at the story's own pace, which contains a culminating insight for the reader at the pinnacle, we are tempted make Milton's overarching comment, which might really be about the relationship between the Spirit and the reader in a Miltonian model of Christian selfunderstanding, instead a theological exposition of Christ's claims to divinity.

Paradise Regained is so often read as Fish has read it: as if it is a glorification of a total death to self, saying (in the words of Kierkegaard’s characterized poet), "I cannot understand the Gospel; between us there is a difference of language which would kill me if I could understand it.” ${ }^{42}$ Additions that "everything [Jesus] renounced is restored to him tenfold” come too late when too tight a focus is already placed on exactly what we are most unwilling to lose, which are not our ways of life, but our ways of thinking — of relating ourselves to ourselves as alone within the structures of our conscious awareness. Fish’s reading of John Milton’s Paradise Regained represents too single-mindedly the destructive half of a death-and-resurrection discipleship, and because of this he gets it somewhat backwards; "resignation,” for Fish, is the path to the pinnacle, where divinity and humanity narratively collide-even though both intertwined narratives, the self-abnegative and the inspired, narratively precede the pinnacle moment.

This is what is missed in Paradise Regained for those who make a saintly wisdom out of the complete silencing of willfulness in the Christian consciousness, which Fish unfortunately does as he cites Augustine's words that "the word of God is not another's to those who obey it"43

${ }^{43}$ Fish, 43 
to mean that God completely appropriates the voice and body of the obedient servant, instead of meaning that the word of God is given to their understanding as their own. Such statements as these remain misleading if they are not qualified by a recognition that the internal depth of consciousness definitive of human life remains intact and active, but simply redirected. Which begs the question: what leads Christ to the pinnacle? What role does the Spirit play in Paradise Regained, narratively or theologically? Is the Spirit's role in Paradise Regained, like the designation of the "Son of God” upon Jesus, "real or allegoric”?44

Dialing back the focus on the negation in “abnegation” to make room for Milton’s curious counter-narrative, we might find a unification of Budick’s and Fish’s interpretations of Paradise Regained: silence is indeed the dominant trope in Paradise Regained, but it is also not the only theme. In fact, it is not a theme at all—silence is an aesthetic strategy, not just of writing but of understanding, used to translate understandings that are deeply complicated by the use of language itself into a (paradoxically) expressible form. It is as a strategy meant to rely on the Spirit's navigation, a mode of passage through the cognitive dissonances standing between the reader and "the fully formed language of Christian experience that Milton is attempting to recreate."45

Remembering that silence is, for Fish, just this (Milton’s aesthetic strategy, by the means of which he communicates indirectly), we can turn now to Søren Kierkegaard's Lilies of the Field and Birds of the Air. Lilies provides another example of the authorial complications imposed on the author of a silent literary work, and through these authorial complications uncovers extensions of Fish’s, Budick’s, and Lewalski’s work that might lead us into a smoother

${ }^{44}$ PR, IV.390

Budick, 124 
interpretation of Milton's alternative narrative in Paradise Regained. By digging into the reflective self-understandings undergirding an authorship hinged upon the indirect communicative strategies of silence, we find that Milton's work ought to peal less into his reader's theological assumptions than it should into the realm of their self-negotiating aesthetic and reflective processes. The remodeled understanding of silence garnered from Kierkegaard in Chapter Two, then, can begin to show us in Chapter Three how it is that aesthetic strategies built around indirect communications rely on a presumed epistemological relation between a cacophony of worldly anxieties, Milton's perplexing comforts, peace, and freedoms, and the Spirit's presence amidst the abysses of resignation. 


\section{Chapter Two: Kierkegaard's Directions}

Using Søren Kierkegaard’s work to help sort out John Milton’s Paradise Regained is possible because in John Milton’s epic poetry we often get, as part of the theme commonly described as "silence," something which Milton himself never refers to as such. As discussed in the first chapter, Milton is not only an author of silent characters in Paradise Regained, but also uses these characters as the structure between which he weaves several intertwining narratives. "Silence," in Paradise Regained, is thus two things. On one hand, it is the process that goes hand-in-hand with descriptions of inspiration, such as when Milton calls upon the Spirit in Paradise Regained to "inspire” his “prompted Song else mute.” On the other hand, however, the pervading concept of silence in Milton Studies also refers to that counter-counter-narrative standing against the counter-narrative exposed by Stanley Fish-the element of Paradise Regained which is successfully communicated precisely because it is uncommunicated, and demands instead a reader’s own practice according to the demands of silence.

Many scholars inspired by Neil Forsyth or Peter C. Herman question whether such a counter-counter-narrative is really to be found in Paradise Regained. ${ }^{46}$ But it is nonetheless there; the “silence” and “inaction” described by Stanley Fish’s reading of Paradise Regained point to the fact that a critical portion of Milton's poem has been intentionally hidden within the things that Milton left conspicuously unsaid or perplexingly unexplained. ${ }^{47}$ And with this determination in mind, there is finally room to fully adjoin the praxis guiding Milton’s attestations of divine inspiration (the "else mute”) to certain methods of subjectifying inquiry:

\footnotetext{
${ }^{46}$ Neil Forsyth's book The Satanic Epic being a handy example of a small group of works published without adhering to the rules of criticism that Peter C. Herman outlined as paradigm-defining in his book Destabilizing Milton: Paradise Lost and the Poetics of Incertitude.

${ }^{47}$ Noam Reisner, Milton and the Ineffable (New York: Oxford University Press, 2009).
} 
those that make use of what Søren Kierkegaard would later call “indirect communication.” In other words, there is finally room to conceptually join the practice that reveals, which is silence, and the content thus silently revealed.

If the style of communication that makes use of "silence” and "inaction" in Paradise Regained is considered as inherently connected to what is communicated by such methods, which seems obvious enough, then Milton’s authorial method appears remarkably akin to Søren Kierkegaard's. This would be Kierkegaard's use of strategies of indirect communication, with one important (and helpful) difference. Kierkegaard, like Milton, designed authorial strategies to communicate certain things precisely by hiding them, forcing readers to confront and even to subvert themselves in the process of trying to come to terms with his work. But Kierkegaard also outlined the procedures by which he imagined proper encounters with the hidden elements of his work could and should occur, which John Milton did not do. "Indirect communication," as it is called by Kierkegaard, is not just something to be subtly discovered in one or two of his writings by another-it is part of the structure of his entire authorship from the bottom up, and something about which he made clear and explicit remarks. ${ }^{48}$

Kierkegaard's explicit deliberations on the subjects of silence or indirect communication, of course, are not explanations or enunciations of what it is that has been left unsaid, or “concealed.” That would defeat the purpose. Instead, they are deliberations about the possibilities or necessities that make room for or demand indirect styles of communication in the first place. ${ }^{49}$ So the point is that Kierkegaard proceeded to reflect directly on the significance of

\footnotetext{
${ }^{48}$ Søren Kierkegaard, Point of View on My Work as an Author, trans. Walter Lowrie (New York: Harper and Row, 1962). Abbreviated POV

${ }^{49}$ We should also note (and this is the inherent trickiness of working with Søren Kierkegaard) that some of the deliberations about the conceptual possibilities or necessities undergirding strategies of indirect communication are not themselves directly deliberations on that subject, and instead can only be considered as such indirectly.
} 
his use of indirect strategies, and thus Kierkegaard enunciated in plainer terms exactly how it is that indirect strategies work and what purposes they might fulfill—all in a way that Milton left, for better or for worse, untouched.

To understand how Kierkegaard would have brought these two elements distinct, but related elements of Milton’s narrative and authorial “silence” together, we need to first understand how Kierkegaard uses the words "silence" and "indirect communication" in his own work, as well as how and why they are only indirectly, and not directly, connected therein. So to introduce the Kierkegaardian concept of silence as “offered with the right hand," and thus “directly,” we turn to Kierkegaard’s "Lilies of the Field and Birds of the Air,” which is found in Christian Discourses. To understand the styles of indirect communication that, according to his own attestations, structure his authorship as a whole, we turn to the relevant reflective moments wherein Kierkegaard hinted at what he was attempting to do with his authorship "as a totality." 50 To bring the two together, and in this process to pull out the hidden transcendental intentions working within the dialectic that guides the Kierkegaardian authorship from the shadows, we work step-by-step through what happens when Kierkegaard applies the "movement" that is the praxis of silence to the “content” given through indirect communication.

\section{I}

So first, what is the Kierkegaardian concept of silence? Exhortations to silence descriptions of it are frequent and typical in Kierkegaard's writings, but they are by no means

${ }^{50}$ POV, 6. 
straightforward. Perhaps the only clear thing about Kierkegaard's concept of silence is that he held it very dearly, considering it one of the most important things he had to say:

And if I were a physician and someone asked me "what do you think should be done?” I would answer, “The first thing, the unconditional condition for anything to be done, consequently the very first thing that must be done is: create silence, bring about silence; God's word cannot be heard, and if in order to be heard in the hullabaloo it must be shouted deafeningly with noisy instruments, then it is not God's word; create silence! ${ }^{51}$

Exhortations such as these are ironic, of course, as Kierkegaard is likely one of the "noisiest" writers of the last two centuries. But the irony here is not accidental. Irony is the first step to understanding the role that “silence” plays in Kierkegaard’s authorial strategies.

Much of the Kierkegaardian authorship is, as many commentators have suggested, "ironical through and through." 52 The main reason for this suggestion is that no reader is ever sure quite why Kierkegaard has written what that reader is currently reading — something Kierkegaard, according to his own attestations, full intended. Kierkegaard wrote under a slew of pseudonyms, and he used these pseudonyms for a variety of reasons. On the surface, it seems that Kierkegaard experimented with the concept of the "pseudonym” to explore ideas that he did not himself believe, to subvert philosophies he had little sympathy for, and even sometimes to settle personal matters. Kierkegaard was careful, though, to make sure that the reader could only guess what the particular reasons for particular authorial attributions might be. Even the explanations listed just two sentences ago are themselves just collective guesses (albeit educated and reasonable ones) made by Kierkegaard scholars about individual works and the intentions

\footnotetext{
51 Søren Kierkegaard, For Self-Examination; Judge for Yourself!, trans. Edna and Howard Hong (New Jersey: Princeton University Press, 1990) 47-48.

${ }^{52}$ C. Stephen Evans, “The Role of Irony in Kierkegaard's Philosophical Fragments” in Kierkegaard on Faith and Self: Collected Essays (Texas: Baylor University Press, 2006), 66.
} 
behind them. The seeds of the ironic are not easy to avoid, in Kierkegaard's writings, even with very attentive study; they can be found in anything that Kierkegaard wrote, simply by virtue of the fact that what is being read might have been written for reasons other than the ones the reader expects.

For some commentators, the only way to reference Søren Kierkegaard himself as an author is to refer to the "author of the Kierkegaardian authors." The problem with translating that designation to his actual writings, of course, is figuring out who that author of the Kierkegaardian authors is in terms of the things written by actual Kierkegaardian authors. Or, in other words, how to puzzle and configure all of the various Kierkegaardian authors within a broader placeholder that makes room for and sense of all of them. As Joseph Westfall notes:

As the aesthetic and the religious are points of view which most readers of Kierkegaard (Kierkegaard himself included) believe to be mutually exclusive one cannot be simultaneously an aesthete and essentially a Christian - then the author of the Kierkegaardian authors is sometimes presenting a point of view that is not his own as if it were his own, and as if his readers should adopt it, too. Taking this attitude to both the aesthetic and the religious points of view (as well, perhaps, as the ethical point of view) over the course of the authorship, Kierkegaard seems in a sense to have been at cross purposes with himself from the very beginning. ${ }^{53}$

These "cross purposes" are not just shallow incompatibilities, though, between different characterized Kierkegaardian pseudonyms. If there was not the opposite concern, introduced by Kierkegaard's remarks that the authorship "as a totality...is religious from first to last," and is the product of an author who "only willed one thing," putting "cross purposes" together would be a waste of time. Westfall, along with many others in the arena of Kierkegaard scholarship, are

\footnotetext{
${ }^{53}$ Joseph Westfall, "Kierkegaard and the Ingenious Creature: Authorial Unity and Co-Authorship in My Work as An Author.” Kierkegaard Studies Yearbook 2010, 267-287.
} 
concerned with figuring out what Kierkegaard the "author of the Kierkegaardian authors” could have been up to. How could such a fragmented authorship be unified? What could such an authorship achieve?

To that end, some Kierkegaard scholars focus on the ways in which the "cross purposes" of the Kierkegaardian authorship considered “as a totality” allow for an indirect engagement with a distinction that, to use Kantian terms, is analogous to the distinction between the understanding and the imagination. David L. Sansom uses this Kantian distinction to get to the heart of one of Kierkegaard's deepest obsessions: the inherently subjectifying tension between appearance and reality. Sansom finds Kierkegaard’s obsession with irony in line, here, with a small citation of Kant's deliberations on "taste”:

In order to distinguish whether anything is beautiful or not, we refer the representation, not by the understanding to the object for cognition, but by the imagination (perhaps in conjunction with the understanding) to the subject and its feeling of pleasure or pain.

Samson interprets these lines, as well:

...We can also envision Kant encouraging those cultivating their aesthetic taste to find effective ways to represent the tension between appearances and reality. Because such representations do not follow predictable patterns of nature and are not the conclusions of a priori deductions, they require the creative imagination. The tension forces us to explore new and revealing ways to engender a subjective state about a reality — that is, beauty-represented in indirect and suggestive ways. ${ }^{54}$

If Samson is right, Kierkegaard obsessed over irony because it exemplifies this tension between appearance and reality, thus heightening one’s appreciation for the subjectivity through which

\footnotetext{
${ }^{54}$ David L. Samson, “Can Irony Enrich the Aesthetic Imagination: Why Kierkegaard’s explanation of Irony is Better than Richard Rorty’s." Journal of Aesthetic Education 51, 2: 17-32.
} 
one must come to terms with these tensions. Samson's “author of the Kierkegaardian authors” takes these words to heart: the ever-present potential for internal irony in Kierkegaard's writings that is introduced by authorial conundrums is a constitutive element of an author trying to develop of his own "aesthetic tastes” by exploring “new and revealing ways to engender a subjective state about reality.”

Samson and others who use such a model run into problems when it comes to mind that the ironic Kierkegaardian style of authorship also uses the Kantian separation of the understanding and the imagination - the replacement of object-reference with the subjectreference — to another end. This separation is exactly what distances Kierkegaard's conceptual authority over the meaning of his own works, considered objectively as their author, from the subject reading his works. There will more on this in the following chapter, but suffice it here to say that Kierkegaard's use of irony may be equal parts for-himself and for-his-reader.

Kierkegaard's irony may not be the development of his own "aesthetic tastes," but an exploration of existentiality geared toward the edification of his readership. As Christine Habbard writes, Kierkegaard may drown his readers in irony "because it paradoxically does away with the illusion of a solid foundational ground from which to start: irony inaugurates genuine existence by dissociating the beginning from the metaphysical question of the origin.” ${ }^{55}$ But does that mean that Kierkegaard himself was, throughout his authorship, still in the throes of a foundationless irony?

If we consider the irony constitutive of Kierkegaard's authorial endeavors as intended for the sake of his readers, a better reading of irony (and its indirect purposes) arises. Kierkegaard's

\footnotetext{
${ }^{55}$ Christine Habbard, “Kierkegaard's Concept of Irony and the Philosophical Issue of the Beginning.” Kierkegaard Studies Yearbook 2009, 269-283.
} 
pseudonymous misdirections replace Kierkegaard's own presence as author, or as the "origin” of the works being read, with the reader themselves. Each work of Kierkegaard's, that is, refers the reader to themselves when that reader searches for a solid, foundational meaning. And if the reader pursues the same kind of solid, foundation meaning—Kierkegaard's meaning—further in Kierkegaard's other works, they will only come up against the same problem once again. Through Kierkegaard's web-spinning of internal referentiality, the possibility of a reader resting on the authority of the web-spinner, inferred from the "object" that is the text itself, remains impossible simply because the possibility of intentional misdirection from that hidden author of authors is ever-present. ${ }^{56}$ Not only might they get it wrong — they might be manipulated.

One such a view, Kierkegaard's use of misdirection looks like an attempt to replicate for his reader, within the scope of his own authorship, a fundamental condition of life as a human being. Most broadly, Kierkegaard's use of irony exposes a reader to a hidden potentiality inherent to the nature of humanity's reflective condition, buried in the way that simply being alive forces choices upon the subject that have no obvious or direct answer. We might say that on Kierkegaardian terms, a human being is like a tree whose limbs occupy not only the area marked out by measures of length and width, but which also, in a reflective sense, inhabit all of the possible space that each limb might have grown into if the circumstances of the tree's growth had been just a little different. The cognitive space occupied by a human being qua bygone possibility is, in its own mind, like a sphere of ideal space that it carries with itself as it proceeds to live in step with the movement of the present moment, invisibly immersed in an internalized nexus of spaces and times.

${ }^{56}$ Westfall, 270. 
Possibilities and hypotheticals and unknown futures compound and intertwine, anchored down by the actual and the necessary into the present, and it is through imagination—and not understanding — that one imagines and reimagines one’s place in the world. Kantian "taste,” for Kierkegaard, is everything. And thus, irony abounds. If it were not for humanity's reflective condition, there would still be irony. Choices and actions would turn out in ways they were not intended to. But there would be nothing that could be noticed as the possibility of the ironic, nothing one might see and fear. Without mankind's inherently reflective condition, there would be no undercurrent possibility of irony to be anxious about, wherein someone could recognize that at the very moment that she hedges her bets in one direction and takes a leap, she may have unwittingly misled herself. ${ }^{57}$

Kierkegaard may begin with irony because it demands a recognition of the ineludible subjectivity inherent to life as it presents itself in the form of an individualized, continuous, conscious experience-as opposed to life as it might be presumed to be in a "factually given state of things." 58 "In sum, if the self is to be separated from the crowd in order to cultivate the ethical and possibly even the Christian religious existence, then irony is what is required. Irony heightens the contradiction between self and culture, which gives rise to human inwardness.”59 And it is only by entering the realm of "human inwardness" (that place to which one turns after the cleansing "bath,” as Kierkegaard calls it, of the ironic) that Kierkegaard’s concept of silence

\footnotetext{
${ }^{57}$ As George Willis Williams describes, "[F]ar more than a rhetorical device or a frivolity that lacks all ethical seriousness, irony is an existential category that is the very seed of the ethically responsible single individual. It is perhaps because Kierkegaard had early intuitions of this that he chose to write his dissertation on irony. In The Concept of Irony, Kierkegaard describes irony as 'the first ... qualification of subjectivity.' One of the theses in his dissertation reads, 'Just as philosophy begins with doubt, so also a life that may be called human begins with irony.' To this he adds that 'no genuinely human life is possible without irony." (George Willis Williams, III, "Irony as the Birth of the 'Single Individual' and the Beginning of Politics.” Toronto Journal of Theology 28, no. 2 (2012)).

${ }^{58}$ As we shall see further on, to work against this "factually given state of things" is the function that will partially define the "religious" consciousness as "religious."

${ }^{59}$ Williams, 309.
} 
can begin to take shape. Through the explanation of the silent inwardness upon which

Kierkegaard meditates in Lilies, we can begin to see how Kierkegaard came to produce an authorship in which the use of indirect communication takes up a space that is first set apart by heeding of the clarion call of Scripture to "create silence.”

One of Kierkegaard's favorite ways to explain himself when he brings up the word "silence" is to refer to the text of Matthew 6:24-34, which he refers to in no fewer than fourteen separate works. This passage of Matthew, an appeal to attend to the teachings provided by the lilies of the field and the birds of the air when one is weighed down by worldly anxieties, offers the lines between which Kierkegaard swims in this second section of Christian Discourses:

No man can serve two masters: for either he will hate the one and love the other; or else he will hold to the one and despise the other. Ye cannot serve God and mammon. Therefore I say unto you, Be not anxious for your life, what ye shall eat, or what ye shall drink; nor yet for your body, what ye shall put on. Is not the life more than food, and the body than raiment? Behold the birds of the heaven, that sow not, neither do they reap, nor gather into barns; yet your heavenly Father feedeth them. Are not ye of much more value than they? And which of you by being anxious can add one cubit unto the measure of his life? And why are ye anxious concerning raiment? Consider the lilies of the field, how they grow; they toil not, neither do they spin: yet I say unto you, that even Solomon in all his glory was not arrayed like one of these. But if God doth so clothe the grass of the field, which today is, and tomorrow is cast into the oven, shall he not much more clothe you, O ye of little faith? Be not therefore anxious, saying, What shall we eat? or What shall we drink? or Wherewithal shall we be clothed? For after all these things do the Gentiles seek; for your heavenly Father knoweth that ye have need of all these things. But seek ye first his kingdom and his righteousness; and all these things shall be added unto you. Be not therefore anxious for the morrow: for the morrow will be anxious for itself. Sufficient unto the day is the evil thereof. ${ }^{60}$

"From the lilies as teachers,” writes Kierkegaard, in reference to this passage, "let us learn silence, or learn to be silent.”61 At the same time, though, Kierkegaard drags out the 
question. What is silence? "This we may learn from the silent teachers, the lilies and the birds: ‘Seek ye first God’s kingdom and his righteousness.” 62 This indirect answer of Kierkegaard’s, pertaining to his “direct” concept of silence but also a direct copying of Matthew’s model, is our first hint that the directly-enunciated concept of silence that Kierkegaard offers in Lilies is inseparable from the concept of "indirect communication" that is characteristic of his authorship as a whole. 'What is silence?' Kierkegaard imagines his reader asking; 'seek not the answer,' he responds, “seek ye first God’s Kingdom and his righteousness.” In the vicinity of silence, such an answer is as performatively direct as it is explanatorily indirect. Kierkegaard puts on display a refusal to address the conceptual thrust of the question directly, and thus he attempts, at the very same time, to address its existential thrust more directly thereby. The reader's experience of Kierkegaard's non-explanation is exactly that kind of reflecting-upon-the-factually-given-stateof-things response which must, with the help of the lilies and the birds, be redirected. And it can only be redirected by accepting the role of the "student" beneath the "teacher" 63 :

But what does this mean, what have I to do, or what sort of effort is it that can be said to seek or pursue the kingdom of God? Shall I try to get a job suitable for my talents and powers thereby to exert an influence? No, thou shalt first seek God's Kingdom. Shall I then go out to proclaim this teaching to the world? No, thou shalt first seek God's kingdom. But then in a certain sense it is nothing I shall do. Yes, certainly, in a certain sense it is nothing; thou shalt in the deepest sense make thyself nothing, become nothing before God, learn to keep silent; in this silence is the beginning, which is, first to seek God's kingdom. ${ }^{64}$

To embark on the path of silence, for Kierkegaard, is not to start figuring out what the deepest silence will eventually be, and thus to solve the puzzle directly and outright. But that, again, is only what silence is not. What is silence? As in the "dialectical movement, or the

${ }^{62}$ Lilies, 322

${ }^{63}$ Lilies, 327

${ }^{64}$ Lilies, 322 
dialectical method" to which we will soon turn, to embark on the path of silence is to begin a process of "becoming silent," 65 a slow and inescapable reorganization of priorities that occurs in two sequential steps. First, "[i]n this wise, a godly wise, one gets to the beginning by going, in a sense, backwards. The beginning is not that with which one begins, but at which one arrives, and one arrives at the beginning backwards"66 — that beginning where one begins is prayer, and the beginning one arrives at is silence. Here, one at the beginning(s) learns that: "In proportion as he became more and more earnest in prayer, he had less and less to say, and in the end he became quite silent." One who is silent, waits: "he had supposed that to pray is to speak; he learnt that to pray is not merely to be silent but to hear. And so it is; to pray is not to hear oneself speak, but it is to be silent, and to remain silent, to wait, until the man who prays hears God." ${ }^{67}$ Second:

When there is silence within thee, then thou dost apprehend, and apprehend with the emphasis of inwardness, the truth of the saying, 'Though shalt love the Lord thy God, and him only thou shalt serve,' and thou dost apprehend that it is 'thou', thou who shalt love God, thou, thou alone in the whole world, thou who art alone in the environment of solemn silence, so alone that every doubt, and every objection, and every excuse, and every evasion, and every question, in short, every voice, is reduced to silence in thine own inward man, every voice, that is to say, every other voice but God's, which about thee and within thee talks to thee by means of the silence. If there never were such silence about thee, and within thee, thou never didst learn or dost learn obedience. ${ }^{68}$

How does one understand these things only "when there is silence”? Kierkegaard does not say. How is it that "silence" leads to this understanding? Again, in a directly conceptual sense, Kierkegaard does not say. But in Lilies, it is made apparent that Kierkegaardian silence is not a loss of subjectivity, considered as the loss of agency and identity one is submitted to beneath the self-abnegation of silent prayer. Instead, "silence” provides the space necessary for

\footnotetext{
${ }^{65}$ Lilies, 322

${ }^{66}$ Lilies, 322

${ }^{67}$ Lilies, 323

${ }^{68}$ Lilies, 336
} 
the reintroduction of the subject to that essential subjectivity that they have always been: the "thou” of the "thou shalt.” Only once one understands their own smallness, and the ensuing paltriness of every worldview which one might attempt to erect as a barrier between oneself and the subjectively-oriented internal demands of scriptural self-negotiation, can one see and hear all of the brightest sounds of silence that are so poetically abundant in the natural world. It is, remember, to the lilies and the birds that one is commanded to look in Matthew 6:24-34. Once one has recognized the silence of "inwardness," this silence can be illuminated throughout the world as one great, connective thread:

In nature all is unconditional obedience. The soughing of the wind, the echo of the forest, the purling of the brook, the humming of the summer, the whispering of the leaves, the whistle of the grass, every sound, every sound thou hearest is assent, unconditional obedience, so that in it thou canst hear God, as thou canst hear Him in the music which is the movement of the heavenly bodies in obedience. And the mettlesome force of the rushing wind, and the easy pliancy of the cloud, and the liquid fluidity of the sea and its consistency, and the swiftness of light, and the still greater swiftness of the lightning-all is obedience. ${ }^{69}$

For the lilies and the birds are unconditionally obedient to God, in obedience they are so simple or so exalted that they believe that all which comes to pass is unconditionally God's will, and that they have nothing else in the world to do but unconditionally to do God's will, or with unconditional obedience to submit to God's will. ${ }^{70}$

The second hint to the connection between silence and "indirect communication," and the second hint to the transcendental purposes that the next section of this chapter will address, is that the "silence" of "obedience" is involved in a turning of the attention toward God and listening with a kind of singularly directed attention that "forgets" anything at all but listening- 
even forgetting the consequences of such an act of listening. Kierkegaard pleads with his reader that they might "forget":

That thou in silence mightest forget thyself, what thy name is, thine own name, the renowned name, the pitiful name, the insignificant name, for the sake of praying in silence to God, "Hallowed by Thy name!" That thou in silence mightest forget thyself, thy plans, the great, the all-comprehensive plans, or the petty plans regarding thy life and its future, for the sake of praying in silence to God, "Thy kingdom come!” That thou in silence mightest forget thy will, thy self-will, for the sake of praying in silence to God, "Thy will be done!" 71

Kierkegaard's repeated use of “forget,” though signifying a loss of self, provides an example of a loss of self that accepts something that can be called a conceptual 'blindness' of silence—simply letting those additions that one adds to oneself in reflection (one's name, one's petty plans and greatest dreams alike) disappear, and with them letting disappear the height of the mountains that one expects to have to climb. Silence is a loss of that kind of reflection back onto oneself that produces willfulness specifically by attempting to add to itself all of its selfdefinitions —in Kierkegaard’s terms, its “culture.”

The closing of the eyes to one's burdens as if they were not there is a common trope in Kierkegaard's veronymous writings (even if they are really there-it is precisely the point that whether or not the burdens are present is not the point, is irrelevant to the internal movement which produces the recognition of subjectivity necessary to simply cleave to the scriptural attestations that there is no reason to worry). In Upbuilding Discourses in Various Spirits, Kierkegaard discusses this turning of the attention as a kind of "meekness," which he defines as “carrying the heavy burden lightly,” or as “gentle courage,” with a bit of Danish wordplay:

Courage [Mod] makes a noise, high-mindedness [Høimod] holds its head high, patience [Taalmod] is silent, but meekness [Sagtemod] carries the heavy

${ }^{71}$ Lilies, 330 
weight lightly. Courage and high-mindedness can be seen, and patience can be seen in the effort, but meekness makes itself invisible-it looks so light, and yet is so heavy. That courage resides within is seen in the eyes, that there is high-mindedness is seen in the posture and glance, that there is patience is seen on the mouth, which is silent, but meekness cannot be seen...

The turning of the attention described here as meekness, and not as silence, is inseparable from the notion of "concealment," which is a hint into the connection that it thus has with the actual concept of "silence." Silence never meant noiselessness—"concealment” and "silence” alike are facets, for Kierkegaard, of the same conceptual inward turn, which is here described again as "meekness":

...The most cunning and strongest enemy is time, especially when it concentrates for the attack and is called the oncoming, the future, because then it is like the fog that cannot be seen close up but the farther away it is seen the more terrible it appears. When patience feels the weight of the future with the eye, one sees how heavy it is, but gentle courage is not worried even about tomorrow. Meekness quickly turns the eyes inward and thus does not see the infinity of the future. ${ }^{72}$

There is no way to draw a simple collation between Søren Kierkegaard’s description of the practice of silence, his personal practices by which he authorially conceals, and what it is that has itself been concealed within the Kierkegaardian authorship. If such a correlative understanding can be reached, it can only be reached in precisely the way that Kierkegaard would not have allowed himself to do. For to assume such a conceptually world-ordering thread pulling together the authorship is, in this authorial context—because of the structuration of this authorship that

\footnotetext{
${ }^{72}$ Søren Kierkegaard, Upbuilding Discourses in Various Spirits, trans. Edna and Howard Hong. (New Jersey: Princeton University Press, 1993), 241-242. We might pay attention, here, to the use of themes directly parallel to Matthew 6:34: "Be not therefore anxious for the morrow: for the morrow will be anxious for itself"
} 
replicates, as we discussed above, the existential isolation of life itself-to ignore the Kierkegaardian lesson entirely: abstraction is always the opposite of a practice of "silence.”

But what about the appropriately dialectical situation in which, performatively speaking, the same conceptual demands which disallow the projection of one's "silence” upon the authorship, considered "as a totality," are the providential proof that such a practice of silence is, in fact, undergirding the authorship as a whole?

\section{II}

The double meaning and use of Kierkegaard's concept of silence-considered indirectly as that which he refuses to address directly, and directly as that which he describes as "silence" explicitly_-is tied to the way in which certain moments of explicit written deliberation in Kierkegaard's corpus inevitably rebound back into the realm of the “indirect.” The direct practice of silence, for example, which is the forsaking of all that about which one speaks (even when one is speaking only in one's thoughts, and to oneself), rebounds for Kierkegaard out into the realm of the "indirect” by becoming an actual practice: “indirect communication.” Or in other words, what might be directly cognizable as a "concept” of silence, once put into practice, becomes an oxymoronic style of performative consistency that, as a practice of the concept of silence, refuses to address conceptual demands directly by addressing them silently. Such a broader notion of “indirect communication” as Kierkegaard’s practical application of the concept of silence incorporates the hiddenness of “meekness” or “concealment,” leaving things unspoken so that those things are thus only recognizable by a reader through the same subjectivelyimaginative ways that Kierkegaard himself recognized them. Which means, of course, that 
Kierkegaard must “conceal” it—if he does not, then it becomes an unearned, and thus unpracticed, and thus unknown insight.

Any connection in Kierkegaard's writings between the concept of silence and the practice of “indirect communication” must, in Kierkegaard's role as an author, be unspeakable; not because it is not understandable, but because to the very act of speaking it shatters the relationship through which Kierkegaard enables his readers to cleave to it. The relationship uncovered between the direct and indirect uses of silence, once made explicit, must also be reflected back away from this "direct” explication into the realm of the more broadly "indirect," thereby made potentially purposeful precisely because it has been thus “concealed.”

Kierkegaardian silence, then, implies more than just the developing link between “Christian silence” and indirect writing strategies. But (and this is part of the "dialectical movement” ${ }^{73}$ of Kierkegaard's authorship) this step is a conceptual reversal of the development of the link produced from the link’s development. For, like Milton’s repetitive application of "silence" in Paradise Regained, the Kierkegaardian authorship represents "the refining and extending of an insight that is never superseded.”74 This insight, or what Kierkegaard's dual indirect/direct style of engagement with the concept of silence implies beyond what a nonKierkegaardian study of Milton's work might likewise bring out, is how an enunciation of the concept of silence that Milton and Kierkegaard share can produce a performative (and thus indirect) fulfillment of the conceptual demands of a successful practice of "silence," considered directly, only by way of remaining reflectively silent regarding its own fulfillment, respected all the way down to the most interior spaces of self-representation. In other words, Kierkegaard's

${ }^{73}$ POV, 6

${ }^{74}$ Fish, 28 
practice of silence might not only be a reader-oriented concern alone. It may also provide the conceptually demanded answer to those same conceptual demands that Kierkegaard refuses to explicitly answer.

This is the aspect of Milton's work that one would be hard pressed to pull from Milton without the help of Kierkegaard. No one has argued, for example, that Jesus's desert silence in Paradise Regained offers a conceptual answer to the Satan’s reasonings. But I believe that Kierkegaard’s authorial example actually follows Milton’s in this specific regard. First, Kierkegaard puts pen to paper in an attempt to work out words that could fit around, albeit not quite into, an enunciation of a purely performative practice of silence. Then, the writings constitute an exemplifying act, not an explanation, of the constituent activity, which is "silence." The object of this activity’s assault is the very concept of reflection, and it is thus practiced, by way of adherence to the rules and guidelines provided in his directly-enunciated concept of Christian silence, by the subject of the Kierkegaardian authorship, Kierkegaard himself. But considered at the broadest level, the Kierkegaardian authorship hides within itself the performance of a unique, dialectical style of transcendental reflection performed upon the very possibility of coming to terms with oneself reflectively through a practice of silence-i.e. oxymoronically—-that seeks its justification.

This oxymoronic style of performative consistency at the cost of splitting reflection itself into two modes, the direct and the indirect, is the transcendental dialectic of Kierkegaard's which I intend to carefully unfold, and in Chapter three will try to translate into the terms of Miltonists' studies of silence, resignation, agency, and inspiration in Paradise Regained. To better explain myself, though, let me invoke Kierkegaard's own words about the activity that guides his writings, then proceed to describe the dialectical style of Kierkegaard's in its plainest terms. In a 
late work, Point of View on My Work as an Author, Kierkegaard makes plain the "single insight" that he cannot "supersede":

This again is the dialectical movement (like that in which a religious author begins with aesthetic writing, and like that in which, instead of loving oneself and one's advantage and supporting one's endeavor by illusions, one instead, hating oneself, removes illusions), or it is the dialectical method: in working also to work against oneself, which is reduplication and the heterogeneity of all true godly endeavor to secular endeavor. To endeavor or to work directly is to work or to endeavor directly in immediate connection with a factually given state of things. The dialectical method is the reverse: in working also to work against oneself, a redoubling, which is "the earnestness," like the pressure on the plow that determines the depth of the furrow, whereas the direct endeavor is a glossing-over, which is finished more rapidly and also is much, much more rewarding — that is, it is worldliness and homogeneity. ${ }^{75}$

The Kierkegaardian style of transcendental reflection, at least as I see it, is defined by a threestep process, each stage of which is a repetition of this “dialectical movement,” a "working against oneself” which begins first by working against the concept of a "factually given state of things." 76

The first step is Kierkegaard's use of characterized pseudonyms to construct various possible epistemological frameworks from the ground, so to speak, of particular, imagined personalities. ${ }^{77}$ The way that each of the pseudonymous characters is guided by a different authorial voice is of critical importance, here, as each of these authorial voices are still internal to Kierkegaard himself, the mediums of thought through which he is capable of running away with an idea in this way or in that. To uncover his transcendental purposes, then, the Kierkegaardian relationship between them that developed throughout Kierkegaard's writings. The order is conceptual, and his dialectical intentions are supposedly present at the beginning, even considering the significant developmental shifts in Kierkegaard's writings throughout.

${ }^{77}$ As some claim, this authorial process of dissociating himself into so many characterizations includes—and on my view must necessarily include-a dissociation from even that character to which Kierkegaard gives his own name.
} 
diversification of authorial identity must be considered as a personal practice, in the doing of which he is actually, as he has attested, working against his own broader intentions_effectively removing the possibility to rely on a "factually given state of things."

Though reflectively intended to help him come fully to terms with the individuality and fullness of his own internal voices, Kierkegaard's use of pseudonyms casts what might have been considered as one unitary author into a broad demonstration of one man's internal disunity, exemplifying in the fullness of his polyvocality the inherent difficulty of rendering a reliable reconciliation, a grounded "self," out of the characteristically discordant voices that he relies upon to reflect. So this diversification of authorial identity erects the chasms that Kierkegaard intends to try to cross: the perceptual-volitional distances between the aesthetic, the ethical, and the religious modes of thought. But it also highlights the implicit recognition that, moving forward, continues to guide Kierkegaard's developing method: a recognition of the inescapable embeddedness of rationality itself in a combination of the mimetic reflexivities of selfcharacterization and the particularity of a given frame of reference-i.e. the scope of the question at hand, or the narrative range of a particular scriptural story.

The second step in Kierkegaard's transcendental method requires the recognition that while each of these imagined personalities and their constructed frameworks represents, on one hand, an individual and direct address to long-standing philosophical or theological points of debate, and on the other also represents just one piece of the now-fractured Kierkegaardian author, together the collection of imagined characterizations points to something further still. The diversification of authorial identity paints into the background of the authorship as a whole, into the space invisibly traversed in the switching of authorial tone from one characterized voice to another, the otherwise-inscrutable "self" that is now made indirectly visible in the swinging of its 
baton as it conducts the whole symphony of voices, ideas, and undercurrent beliefs. So while on the reflective level, the unitary authorial self of the Kierkegaardian authorship is dissolving conceptually into so many different faces and sounds, on another level a new understanding of selfhood is appearing -ineludible subjectivity, the continually becoming self one cannot help but be, and through which one defines oneself qua aesthetic, ethical, religious, etc. indirectly in the present choosing, at each and every moment, of the mode and temper of one's own selfconception as such.

In the context of Kierkegaard's readers, this singular self is simply an internality to which they are being pointed as they try to keep up. But in the context of the Kierkegaardian authorship’s production, this interiority is authorially personal-the coordinating Kierkegaardian voice which speaks only by way of its silence, or the space between voices as it bounces around between veronymous and pseudonymous works. In its bouncing about it betrays, albeit only ever indirectly, the intentions of the shadowed and hidden author behind it all, "author of the Kierkegaardian authors.” In Point of View, Kierkegaard writes:

This movement was traversed or delineated uno tenor, in one breath, if I dare say so - thus the authorship, regarded as totality, is religious from first to last, something anyone who can see, if he wants to see, must see. Just as one versed in natural science promptly knows from the crisscrossing threads in a web the ingenious little critter whose web it is, so an insightful person will also know that to this authorship there corresponds as the source someone who qua author "has willed only one thing." The insightful person will also know that this one thing is the religious, but the religious cast completely into reflection, yet in such a way that it is completely taken back out of reflection into simplicitythat is, he will see that the traversed path is: to reach, to arrive at, simplicity. ${ }^{78}$

\footnotetext{
${ }^{78}$ POV, 6-7.
} 
The third step of Kierkegaard's implicit transcendental method, then, addresses the return to simplicity. The "religious" is, for Kierkegaard, now quintessentially attached to the simultaneous (1) impossibility of escaping the responsibility-inherent volitional valences of relating oneself to oneself in reflection that can be seen indirectly and (2) the thus exposed impossibility of replicating the same self-relation directly, or by way of specific, reliable, grounded, and/or explicable concepts. Such a groundedness, reliability, or satisfactory explicability of oneself and one's conceptual relation to other possibilities of understanding is precisely the illusion, for Kierkegaard, that one who does not understand the depth of his or her own subjectivity erects for him- or herself by the very act of reaching for it —an act that, indirectly speaking, he or she is thus responsible for.

At each and every conscious moment, the reflective Kierkegaardian subject performatively defines themselves in the present act of choosing the methods or patterns of thought by which they will attempt to define, discover, or become themselves. Subjectivity is inescapable. But it is not impossible to influence oneself indirectly. In fact, the inherent necessity of existential choice proves that the "self,” on Kierkegaard's terms, is by definition guidable, negotiable, and in that sense become-able; all to the same degree that one understands how this creative process must take place unreflectively, inscrutably, and internally, even if it is also performed authorially.

So what is the final step, then? What is the "traversed path," and what does it mean "to reach, to arrive at, simplicity”? Simplicity is, properly speaking, the ubiquitous return of subjectivity, by way of the initial subjectifying intuition inherent to the second step, through which the hermeneutic circle of religiosity is succinctly and summarily closed. For Kierkegaard, a new possibility for indirect self-engagement breaks the necessary internal ground for the 
introduction of "earnestness," or a true self-negotiation as guided by the same demands that one might have held oneself to already absent the entire authorial reflection: the scriptural demands of "silence," directly considered. Freshly reintroduced to oneself as a univalent self-in fact, freshly introduced to the inescapability of responsibility that is reducible to oneself, to the ineluctability of existential self-definition as oneself-the primary lesson is that one did not beforehand completely understand the depth of the discipline already supposedly in practice, which is the interiorization of the "thou shalt" of scripture. ${ }^{79}$

In the enunciation of Kierkegaard's own third step inherent to this peculiar method, we find that for Kierkegaard the "religious" is nothing more and nothing less than it was from the first: the scripturally-proffered, prayerful reformation of the self by way of silencing one's own internal willfulness(es), now traced all the way down to the voices with which one speaks to oneself internally in reflection. There is one telling difference, though, between such a practice of silence as it might have occurred prior to this transcendental deduction of essential subjectivity and such a practice of silence as it might occur afterwards. This single iota of indicative difference, which sets two otherwise identical modes of self-relation (religious and religious $^{\mathrm{a}}$ ) a world apart, is the inability of the latter to refer to itself, at the broadest level, as fulfilling the demands of reflective inquiry—for it is aware of the implication that such a statement is a contradiction of the indirect/direct terms on which the dialectic rests, and implies a forsaking of the praxis of silence that casts the whole project back into the realm of the reflective, out of the realm of the earnest, inward, and subjective.

\footnotetext{
${ }^{79}$ This “Thou Shalt” emphasis is not unique to Lilies, but comes up in a variety of Kierkegaard's writings, including Works of Love, his most famous veronymous work.
} 
In other words, reflective silence demands that one remains reflectively silent about one's reflective silence. For Kierkegaard, this means remaining silent about the form and success of his hidden transcendental reflections; for Milton, as we shall see in Chapter three, this means remaining silent as to the ways in which one's poetry about silence must abide by the form and function demanded by its author's practice of silence. The key piece of interpretive evidence developed in Chapter three will be that Milton and Jesus alike would not say what they were up to in Paradise Regained. Jesus’s silences and Milton’s silences, though on one hand narrative and on the other authorial, each represent the primacy of scriptural obedience over reflective justifiability.

To many, the primacy of scriptural obedience over reflective justifiability smacks of antiintellectualism. To authors like Milton and Kierkegaard, though, that might be a good thing. For in a Kierkegaardian dialectic, an appreciation for the primacy of obedience over explicability displays the depth of one’s “religious” sensitivities — which do not ignore, but instead deeply incorporate the structures and demands of reflectiveness by way finding solace in existentiallyinternalized obedience. In the following chapter, to which we now turn, I argue that Kierkegaard and Milton find a mutuality in this "insight which is never superseded," a performative process of silencing oneself by letting be produced in one's own thoughts, words, and deeds the whole range of "virtues" by which one might come to know oneself as religious ${ }^{\mathrm{a}}$, reflectively speaking - expressions such as meekness, earnestness, hope, faith, love-but the expression of which conceptually denies the exact stripe of self-reflexivity which leads to these expressions being recognized by the one who expresses them as such. 


\section{Chapter Three: A Pair of Simplicities}

If Chapter One offers a taste of the discursive atmosphere surrounding John Milton’s 1671 epic, Paradise regained, while Chapter Two summarizes a few of the more hermeneutically- and transcendentally-oriented elements in Søren Kierkegaard's writings, then this final chapter serves to bring the two preceding parts together. Because of the general nature of working with Kierkegaard, though, we should note from the outset that the incorporation of Kierkegaard is not meant to complicate the issues at the heart of Milton's epic poetry. Rather, his work is intended to add a bit of clarity to what has, in the study of Paradise Regained, become a bit muddied: Milton's use of indirect communication to pair authorial and narrative silences, hiding his dialectical intentions within the shadowy figure of "Thou Spirit."

That said, Søren Kierkegaard is a notoriously cryptic author, so complexity is unavoidable. Moreover, belaboring the reflexivities of Kierkegaard's authorship is necessary for this analysis of Paradise Regained to succeed, and for that reason the intricacies of Kierkegaard's method of "indirect communication," as well as its indirect relationship to his concept of Christian "silence," needed to be introduced first. But from here forward, Kierkegaardian "simplicity" is the bridge between these two radically individualistic thinkers; not because "simplicity" is a means by which something else might be communicated more clearly, but because Kierkegaardian simplicity, with all its epistemological connotations, is itself what should be introduced into the study of John Milton's epic poetry, and in particular to the study of Paradise Regained. It is simplicity that, for the purposes of this final chapter, will stand in for the link between Kierkegaard's and Milton's concepts of Christian silence, as well as denominating the connection that these respective concepts of silence bear to the two authors' strategies of indirect communication. 
To finally begin using Kierkegaard's work as a guide through Paradise Regained, then, means to focus no more effort on the nuance or complexity of the Kierkegaardian toolset. Instead, the way is now straightforward, following an explanation of the essential "simplicity" that Kierkegaard's curious strategies are born out of and are ultimately geared back toward. This concept of simplicity leads smoothly into a negotiation of the epistemological questions posed by Milton's narration of Christ's journey into the desert, and in doing so shows that Milton's epistemological quandaries can be read as rooted in his own understanding of a kind of existential simplicity undergirding human understanding. Simplicity, through its peculiar reversals of the concepts of resignation, faith, agency, obedience, and understanding, sheds some much-needed light on Milton’s narrative progression via “silence” and “inaction” in Paradise Regained. Specifically, a concept of simplicity sheds light on how Milton's narrative progression is not only followed by its own subsequent negation in or after the pinnacle scene, as is introduced explicitly in the near-final lines ("Now enter, and begin to save mankind" ${ }^{80}$ ), but is also one half of a dialectical interplay between two narratives running parallel to one another throughout the poem. These two narratives are at once the negation and the negation of the negation; in other words, one is the narrative guided by the self-abnegation of Christ's and his followers' resignation to simple obedience, while the other is the freedom that negates this selfabnegation achieved—albeit only indirectly—by His perfect obedience.

In other words, Milton's narrations of Christ's desert temptations chase the logic of a faith-by-resignation discipleship to its utmost, and Kierkegaardian “simplicity,” which links indirect communication and strategies of silence, ultimately reveals the Aristotelian reversal through which Paradise Regained is turned on its head. This Aristotelian reversal of Paradise

${ }^{80}$ PR, IV.635 
Regained, noted by Price McMurray and through which he highlights the dialectical relationship between Milton's Christian understandings and classical education, is Milton's use of the "highest” poetic strategy listed in Aristotle’s Poetics to bring out the dialectical birth of Christianity from its opposite, which it also is: freedom from obedience, faith from resignation, ignorance from knowledge, and knowledge from ignorance.

It looks admittedly misleading, of course, to argue that Kierkegaardian "simplicity," a supposedly simple concept, leads to a reading of John Milton's Paradise Regained that finds faith to be an existential negation of a negation, an active double-negative in which the second half is both made possible by and entirely subverts the first. What is more, to focus on what I am calling Søren Kierkegaard’s “simplicity," pulling the word from the "pregnant little backward glance" found in Point of View on My Work as an Author, is to draw attention to an underemphasized element of Kierkegaard's writings in the first place. ${ }^{81}$ In ways both fruitful and otherwise, Kierkegaard's is a reputation centered on paradox, dialectic, and circularity. It is not for the sake of irony, though, that we turn now to reversing that reputation, or to turning Milton's concept of resignation on its head. If to understand Paradise Regained requires understanding the Aristotelian reversal at its pinnacle, and if the narrative of Paradise Regained is decidedly one of resignation, then perhaps the failure to conceptually reverse Milton's concept of resignation is exactly the mistake still being made today. ${ }^{82}$

\footnotetext{
${ }^{81}$ Westfall, 273.

${ }^{82}$ Referring generally, here, to the argument put forward by Price McMurray that there is a disjunction between Milton's treatment of Philosophy vis a vis Christ's arguments with Satan, on one hand, and Milton's incorporation of Philosophy vis a vis his usage of classical models, such as the Aristotelian theme of reversal, on the other. More specifically, I am referencing this "reversal” of Milton's as evidence that there is something in Paradise Regained that needs to be reinterpreted post-pinnacle (Price McMurray, Aristotle on the Pinnacle: Paradise Regained and the Limits of Theory. Milton Quarterly, 32 (1998): 7-14).
} 


\section{Kierkegaard's Simplicity}

Kierkegaard's notorious inscrutability as an author is not all bad. It tends to keep his readers careful, keep them hermeneutically occupied with themselves as his readers, and to aid in his general project of hiding himself from his readers so that they look more discerningly at themselves. This same inscrutability, though, tends to also do something else: obscure the plainness upon which his authorship is built. The whole authorship, in fact, could perhaps be read one of the best baiting exhibitions of the familiar colloquialism, "to miss the forest for the trees," that has ever been put into writing. If the "trees" of the Kierkegaardian authorship are the characterized frames of mind through which Kierkegaard writes individual books (and in the midst of which the "forest" that is the elusive "SK," author of authors, is dialectically lost), then Kierkegaard's "simplicity," or what I mean to highlight with the word "simplicity," is simply the fact that these "trees" are all rather straightforward constructions when they are considered by themselves.

Despite the fact that any given characterized author may discuss, confront, or even reflect back on the dialectics that make Kierkegaard's work the mysterious series of contradictions that it is, these characters are inevitably singular. Because of this, the characterized authors of individual works must always be considered in the light of the essential univocality which each author individually represents, in such a way that the designation of "simple" refers to the way that these characters are always speaking singularly out of the "aesthetic," "ethical," or 
"religious" categories, and cannot be speaking out of more than one of these at once. ${ }^{83}$ The ratio of author-to-work is the linchpin of Kierkegaard's endeavors. Every characterized frame of mind has its degree of intricacy, of course, and part of the beauty of Kierkegaard's work is that these characterizations are so rarely painted fools. But that would not be enough to set Kierkegaard's work apart from the playwrights whose theatre he was so fond of, or even from the Hegelians whose philosophies he struggled so diligently against.

The particular kind of complexity that sets Kierkegaard apart, and the reason that an understanding of dialectic and misdirection are conceptually indispensable in a proper reading of his work, comes from Kierkegaard's recognition that the frame of mind definitive of one character (e.g. the aesthetic frame of mind) cannot not be related to another character's frame of mind (e.g. the ethical) without this relation taking place within one, the other, or a third character's point of view. This much has been said already, of course, but here simplicity is the key ingredient. No matter which way or wherefrom the relation of author-to-book is oriented, in each case that relation is always simply and singularly that one which it is, and that alone-one cannot be aesthetic, ethical, and religious simultaneously, for if one speaks in the voice of the aesthete then one is, by definition, not speaking ethically or religiously.

In other words, Kierkegaard's characterization of his authorial personalities and the meanings available to them in reflection are inextricable from one another. Meaning is always, for Kierkegaard, simple. The character designated by Kierkegaard as the "aesthete” is thus designated because that character says and thinks aesthetically—he simply says things

\footnotetext{
${ }^{83}$ Characters may vacillate, as Kierkegaard tended to characterize vacillation in his transitional authors (Johannes de Silentio or Johannes Climacus, for example), but even these transitional authors cannot simultaneously inhabit two distinct frames of mind at the same time. Instead, they are torn between the two in such a way that they are often neither here nor there, but are instead stuck in some nowhere in-between.
} 
differently, or says different things, than the character who is thinking "ethically.” To see the "simplicity" inherent to such a notion of conscious reflection is to see the difference between the aesthetic and the ethical, or between the ethical and the religious, as being located in the irreducible act of enunciation that gives substance to the speech and thought of each of these characters for themselves. Specifically, this difference is between the relationships that obtain between sayer and said when they take the solidified form of the existential declaration.

The aesthete declares that "aesthetic" means this, "ethical” that, and that the two words relate in such and such a way. In outlining what he or she believes to be true, the aesthete separates his or her truth from that of the "ethical” character's beliefs, patterns of thought, and declared realities. Whether one is persuaded by this, and the other convinced by that, is all beside the point: in each case, the shape of the disagreements between the perceptual realities that each character prioritizes for themselves classify one as "aesthete” and the other as "ethical," and do so by way of the decision each character makes to place an existential weight on one side of any particular either/or (regardless of how many “eithers” and “ors” there actually are), declaring their own simple meaning of whatever words and concepts are being thus organized.

This much is still obvious, of course, but the point is not the nature or obviousness of this problem. The point is the way the Kierkegaardian authorship works with meanings that must always trace their roots to these prior simplicities, which means the authorship itself is not grounded in ambiguity and groundlessness except in the ways that ambiguity and groundlessness can arise in the midst of characters who have themselves already taken a definitive shape, and who have come to do so by way of simple declarations about the realities they inhabit. Each character has something unique to say, a personal content of beliefs that can be expressedwhich is how the various characters even have the capacity to produce books in the first place. 
The problem involved in transitioning from these simplicities of the Kierkegaardian authorship into the complexity of trying to understand the authorship "as a totality," then, with all its murkiness and ambiguity, is the subjective-objective implications that complicate the essentially simple character of any single individual's understanding. The nature of relating one character to another only through individualized points of view, however various, denies the possibility of objective analysis. In fact, the more diverse points of view are added, the further away objectivity itself is thrown. Objectively speaking, the word “aesthetic” refers to "“aesthetic” qua aesthete,” “‘aesthetic’ qua ethical,” and ““aesthetic' qua religious” simultaneously, and with more points of view the word only means more contradictory things—nothing that we, in the wake of post-modernism, are unfamiliar with, but something that we might fail to appreciate in the same ways.

For while the various meanings of the word "aesthetic" introduces no small doubt about the possibility that "aesthetic" has an attainable objective meaning against which to measure all of these various subjective meanings, the deduction of such a doubt about the "objective" has actually skipped a step. What is overlooked is the fact that there never was a detached, objective point of view whereby a word like "aesthetic” could actually have meant all of these different things simultaneously. On Kierkegaard's terms, each of these different uses of the word “aesthetic" has its individual meaning only by way of the essential simplicity within which it was first entangled: the declaration made by a single individual that the word aesthetic does, in fact, mean this. More importantly, these contradictory simplicities cannot cohabitate in one thought. “Aesthetic” does not just mean this, for the aesthete, but means this and not that. There are not multiple, simultaneous views about the definition of "aesthetic" — there is an abundance of single views from individual vantage points, and that makes all the difference. 
If the two concepts, “'aesthetic’ qua aesthete” and “'aesthetic’ qua ethical,” are simultaneously related to one another in the head of an individual subject, which they must be if the two concepts are to be related thoughtfully, then in reality one has entertained the thoughts of neither the aesthete nor the ethicist, for the meaning-making movement behind each which identifies one as the "qua aesthete" and the other as the "qua ethical” has vanished. The aesthete does not relate to the aesthetic with a maybe; it is through the perception of the ultimacy, or perhaps the universality, of the aesthetic as the substance of his own life and thought that the aesthete declares the priority of the aesthetic life as a real, objective truth. To entertain the notion of the "objective" as regards the multiple meanings of the word "aesthetic" — and to think that by doing so, one is actually relating the thought of the aesthete to the thought of the ethicist-is an imagination. What is more, such an imagination has not only not stepped beyond the simple meanings of “aesthetic," but has actually fallen one step short of them. One enthralled by the objectivity dilemma itself, let alone whatever attempt might be made to handle the dilemma, is only beginning to participate oneself, qua individual, in what each of these singular characters supposedly being compared were already doing themselves, right up until they made their own simple declarations about the meaning of "aesthete" that is true for them. For as long as two such concepts are not simply related, but are instead reflectively related as if a conceptually “direct” relation is possible, the two concepts are never related at all.

The illusion of objectivity, on Kierkegaard's terms, does not shutter out the possibility of Truth, capital T. Such an interpretation actually inverts the intention behind the subjectification of Truth that Kierkegaard is after, and inverts it specifically by reintroducing the imaginary “objective” position as its obstacle. Kierkegaardian "simplicity” overcomes the obstacle of objectivity not by recognizing and outsmarting it, but by subverting it - the "obstacle" is an 
erroneous imagination that fails to accept the responsibility-inherent volitional valences of acts of perception, which are irreducibly subjective. For Kierkegaard, truth, meaning, and the like are found to have been at home within the realm of the subjective all along, but only in such a way that the projections of “objectivity” inherent to believing something "true,” and thus making one's words refer to something (i.e. have meaning), is baptized by its incorporation into the essential subjectivity in, through, or with which each person, qua individual, lives. The Kierkegaardian existence demands an acceptance of the existential simplicity required to subjectively declare one's own objectivity, which on such a model becomes the only thing capable of producing referential meanings that seek to transcend the subjective/objective boundary.

Part of the definition of the subject as a subject, then, is the act of declaring the objectivity which is the shape that Truth or Meaning takes "for me,” yet somehow simultaneously remembering that this truth or meaning is held by belief, and not by certainty. ${ }^{84}$ The model is divisive, requiring internal divisions that trouble the coherence of selfconsciousness altogether unless that model balances, and not eviscerates, the relationship between passion and reason. Passion, for Kierkegaard, becomes the key: it lifts the individual above the emptiness of the crowd, the multitude, or "humanity." Why? Because for Kierkegaard, the individual alone thus has subjectivity, or the capacity to choose, declare, believe, and through these things to "become a self.” The Kierkegaardian notion of the "crowd” is a current, something upon which the individual can drift along just as if he or she is moving, but without

\footnotetext{
${ }^{84}$ Quote pulled from Kierkegaard's Journals (August 1, 1835): "What I really need is to get clear about what I must do, not what I must know, except insofar as knowledge must precede every act. What matters is to find a purpose, to see what it really is that God wills that I shall do; the crucial thing is to find a truth which is truth for me, to find the idea for which I am willing to live and die”
} 
even an ounce of energy spent; only within one’s internal, subjective-objective dialectical existence, for Kierkegaard, can one muster up the existential energy necessary to truly move.

In sum, then, Kierkegaard prioritizes subjectivity not as a weapon aimed to strike at truth, meaning, and the like, but as a weapon against the "leveling processes" of reflective objectivity that holds life “at arm’s length,” and with such a posture threaten life itself, even if one thinks of oneself as thus unharmed. ${ }^{85}$ The concept of objectivity, and through it the reflective space that admits the hypothetical play between things purely ideal, retains a meaningful activity only if it becomes part of the process of defining the objectivity that is "mine" — which is not to deny that objectivity, but to subjectify it by (perhaps for the first time) believing it.

Kierkegaard sometimes writes that the individual’s existence is part of “eternity,” “infinity,” and “freedom” as much as that existence is also part of “temporality,” "finitude,” and “necessity.” Simplicity, the root of the capacity to believe which can lead to a fulfilment of subjectivity through its unification with the internalized objectivity which it is (by the act of externalizing itself in the declaration), is in direct connection to an existentially-laced division. Such a description of subjectivity can perhaps best be read in the remembrance that Kierkegaard did sometimes, albeit rarely, make overt claims. He had an “objectivity” of his own, which was largely informed by his intense scrutiny of the possibilities involved in the dialectical relationship between subjectivity and objectivity in "being." The shape of these claims of Kierkegaard's are, in many ways, part of his debt to Immanuel Kant.

Immanuel Kant's deduction of the transcendental ego, in which the whole deduction is principally conditioned by the only-indirectly-seen activity which facilitates the very possibility

${ }^{85}$ Kierkegaard's Journals and Notebooks, NB 28:52 
of "identity" itself, sparked a conversation that changed the shape and scope of the philosophical enterprise. ${ }^{86}$ Just as Einstein led the world into a total remodeling of the universe when he gave a new, more definite shape to the conceptual division between energy and matter, Kant's transcendental projects led the world into an immense struggle against the problem of reorienting identity’s relation to itself after the explosive transcendental fission of will and word-that is, between the only-indirectly-seen activity that makes oneself an "identity" and the identified content that one relates to directly when one tries to relate to oneself. ${ }^{87}$

Though an obsession with this division is by no means in Kierkegaard's writing first, it has an inimitable importance here, for Kierkegaard's use and understanding of this rupture of identity is unique. Kierkegaard takes the rupture between the activity and content of identity into his thought not as a conceptual problem, but as an existential burden. He does not seek to figure out, except in the process of overcoming it. The sense of the division between the will and the word, or between the identity and the identified, scars to the heart of "being” in Kierkegaard's work largely because it is scarring into the heart of his actual, individual being - the heart of S.K., the person behind the writings who is searching for the reunion of these two sundered pieces.

These existential leanings go to show only one thing: even if the whole of Kierkegaard's authorship is bent toward the academic purposes of picking apart humanity’s dialectical consciousness — and they are-Kierkegaard did not bear the existential weight, qua author, of splitting himself up in accordance with the dialectics of human understanding only because he

\footnotetext{
${ }^{86}$ Kant, Immanuel, and Norman Kemp Smith. 1929. Immanuel Kant's Critique of pure reason. Boston: Bedford. P 151-155 (DEDUCTINO OF THE PURE CONCEPTS OF THE UNDERSTANDING, Section 2, ๆ 15-16).

${ }^{87}$ For a good study on this tradition out of Immanuel Kant's work and its effect on Kierkegaard's thought, see: Samuel Loncar, "From Jena to Copenhagen: Kierkegaard's Relations to German Idealism and the Critique of Autonomy in The Sickness Unto Death." Religious Studies 47, no. 2 (2011): 201-16.
} 
felt that the pursuit of knowledge demanded it. It is precisely Kierkegaard's overarching emphasis on simplicity, which is how the possibility of meaning is itself buried in individual declarations, that displays how the pursuit of objective certainties must, on an existential register, be an ultimately vain and fruitless effort. So just as Kierkegaard's dialectical method sits somewhere between logical analysis and expressive performance, bent on learning both what and how to believe by playing endlessly upon the dialectical interrelatedness between these two ends, so also must we remember that the fuel propelling the Kierkegaardian authorship as a totality should not be reduced to analytical or intellectual purposes alone. To do so is to forget Kierkegaard's own constant reminders that he bore the weight of his own authorship only because he wanted to offer his reader, qua "single individual," the opportunity to truly bear the weight of a "genuinely human existence.” The authorship is not a compendium, nor an analytical method, but an invitation — to miss this fact not only warps the authorship as a whole, but actually gets it all precisely backwards.

If the personal passion inherent to Kierkegaard's work is missed, if the activity which it pursues is not prioritized over the content it produces, if a reunion of the will working itself out across the pages and the words thus there upon them is not seen within it as the tantalizing carrot hung in front of every transcendental movement, then the dialectics of Kierkegaard become an existential masochism of despair — the will letting itself be run out of the soul with the whip of necessity at its back in relentless pursuit, guiding the individual all the while not toward life, vis $a$ vis subjectivity, but toward an existential death. Kierkegaard's whole transcendental endeavor is not to capture and subjugate the substance of life by trapping it in rule and causality, but to learn how to keep up with it as it runs. Only with this one critical element in mind, the element of simplicity, can Kierkegaard's authorship be seen as the exhibitive, dialectical process of 
“becoming a self," and in particular, as he says it, making himself into "someone who could be needed in a crisis, as a guinea pig that life uses to feel its way.”88

\section{John Milton’s Simplicity}

Taking a step back, then, it may already be apparent that the final move into John Milton’s work is by the analogy to be drawn between Søren Kierkegaard's authorship and John Milton’s Paradise Regained. The temptation to interpret Søren Kierkegaard’s authorship on analytical or objective terms is analogous to the temptation to draw a propositional understanding of resignation or discipleship from John Milton's Paradise Regained — that is, an understanding that answers the objections to substance or coherence raised against Milton’s 1671 epic, or at least tries to answer them straightforwardly and on their own terms. Describing these kinds of answers as a "temptation,” of course, does not imply that objections to the substance or coherence of Paradise Regained are utterly unanswerable. Milton’s portrayal of Christ’s desert temptations and pinnacle triumph, when read with an eye toward directly answering Russell Fraser's or Peter C. Herman's concerns about the poem and its interpretation, ${ }^{89}$ ironically fails to appreciate the indirect understanding of Christ's desert temptations that, though only hinted, implies a radically individualistic and subjectifying answer to these concerns remarkably in-tune with Søren Kierkegaard’s writing strategies and his undercurrent concept of Christian silence.

To display the Kierkegaardian elements of the model of subjectivity working beneath John Milton's Paradise Regained, and through Kierkegaard to read Paradise Regained as a

\footnotetext{
${ }^{88}$ Kierkegaard, Søren, and Walter Lowrie. 1967. Stages on life's way. New York: Schocken Books.

${ }^{89}$ To the former, objections that Milton's poetry eschews particulars, and thus is not even poetry, but another form of Platonic nonsense; to the latter, objections to the interpretive principle that Milton's poetry is coherent.
} 
subjectifying work of art purposed toward strengthening the individual's capacity to understand God's inspirational intimations (and not primarily purposed toward resigning to the fact that some things will always be unknowns), the best beginning is to return to John Milton’s perplexing little poem “When I Consider How My Light is Spent.” In it, John Milton questions his own capacity to serve God after suffering blindness (as well as, perhaps, the degree to which he deserves the blindness in the first place), and proceeds to ask whether or not the inability to make use of his God-given talents will be held against him. Traditionally, the emphases within Sonnet XIX are read as signs of an uncharacteristic resignation to passivity:

When I consider how my light is spent, Ere half my days in this dark world and wide, And that one talent which is death to hide Lodged with me useless, though my soul more bent To serve therewith my Maker, and present My true account, lest He returning chide; "Doth God exact day-labor, light denied?" I fondly ask. But Patience, to prevent That murmur, soon replies, “God doth not need Either man's work or His own gifts. Who best Bear His mild yoke, they serve Him best. His state Is kingly: thousands at His bidding speed, And post o'er land and ocean without rest; They also serve who only stand and wait."90

In a piece aptly titled “They Also Perform the Duties of a Servant Who Only Remain Erect on Their Feet in a Specified Place in Readiness to Receive Orders,” Carol Barton notes that Sonnet XIX is most often read with an emphasis on the tragic expectations produced by the poem — that Milton has worked so hard to cultivate his gift, wants so ardently to serve, and yet

${ }^{90}$ Milton, Sonnet XIX. 
that this service is exactly what God, for some unknown and inexplicable reason, denies. ${ }^{91}$ "As a result of this persistent and enduring misrepresentation,” she says, "Milton scholarship has traditionally considered the poet's initial meditation on his blindness to be an anthem to passive resignation." ${ }^{92}$ But passivity, she argues, is the furthest thing from Milton's aims in the last few lines. Interpretation has been misled, she thinks, from false emphases being placed on two words: "also" and "only” in "They also serve who only stand and wait."93

I contend that it would have been unbearable, if not impossible, for someone of Milton's talents, ego, and aggressive temperament to subscribe even momentarily to the kind of namby-pamby "pity poor me" resignation implicit in the historical reading of this line, and that traditional rhetorical emphasis on the word "also" has likewise put the pivotal accent squarely on the wrong syllable in terms of the speaker's meaning. Rather than a sigh ("they also serve, who only stand and wait"), I contend that the final line of the poem is an emphatic declaration (they also serve, who only stand and wait") a subtle difference that makes a monumental difference in the perspective of the speaker, and relies on the key definitions of the words serve, stand, and wait quite different from those given in this context by the OED. ${ }^{94}$

Barton's verdict that relying on common uses of the words serve, stand, and wait, which are indeed nuanced terms in Milton's prosaic and poetic vocabularies alike, is spot-on. But there is another point to be made—one which Barton herself drew attention to, yet went undeveloped in her work as she pursued the alternative emphases provided by the connotations of Milton's uses of the words serve, stand, and wait. This additional point is the logical, and not simply rhetorical, function of the word "also." Specifically, the directionality involved in the identification of two conceptually different meanings of the word "serve," which takes place in the final line by way

\footnotetext{
${ }^{91}$ Barton, C., "They Also Perform the Duties of a Servant Who Only Remain Erect on Their Feet in a Specified Place in Readiness to Receive Orders”: The Dynamics of Stasis in Sonnet XIX. Milton Quarterly, 32: 109-122.

${ }^{92}$ Barton, 110

${ }_{93}$ Barton, 111

${ }^{94}$ Barton, 111
} 
of the word "also," can be a key point of misinterpretation when read in reverse. Just as saying that a bull is like a mouse makes an entirely different remark than saying that a mouse is like a bull, comparing the stand/wait passivity to the speed/labor activity can be misleadingly backwards when too strong an emphasis is placed on the negative aspects of resignation.

The "also" in "they also serve, who only stand and wait," is often read as collating standing and waiting with the service of those who "at His bidding speed, and post o'er land and ocean without rest." When the collation is thus framed—stand/wait is really to speed/labor—-the obviousness of the disjunction separating the two activities becomes the source of a reasonable discomfiture with the answer. Faced with a question like "Why would God keep a capable servant from serving, and force instead his resignation as a work through which to display his faith?" the presumption is that Milton must resign to resignation. Often, this difficulty to embrace what feels like a meaningless exercise is interpreted as something which Milton emphasizes because it is a reality particularly difficult to embrace: it takes a true patience, so the line goes, to trust in God when one sees so clearly the exact opposite of what God has apparently inclined, and cannot entirely figure out why one must do the opposite. On such a reading, Milton's example becomes one in which the heart cries out that 'Performing my service is better than simply waiting,' and Milton may even be crying out in fear of this, or in self-pity—and precisely because the heart thus cries, Milton makes the point that to really obey means to trust in God anyway. In fact, emphasis on such a kind of resignation as this example forms the central thrust of Stanley Fish’s interpretation of Paradise Regained discussed in Chapter One.

But what if the collation is reversed? What if, in the opposition of the two types of service to God being identified, the conceptual difference between these two types is what is being dissolved in the first place? What if the interpretation that one must patiently resign to 
one's affliction and trust in God despite a total lack of knowledge about how or why one is thus afflicted misses the counter-understanding that transforms Milton's language regarding "service” altogether? For as Milton begins, the worry is that God might “exact day-labor, light denied”; service rendered to God is “day-labor.” Milton is worried that he has done something wrong because he has assumed that God would want service and faith above just faith. At the end, though, the reply is that “God doth not need/Either man’s work or His own gifts. Who best/Bear His mild yoke, they serve Him best.” "Serve” has been redefined; if the word also is taken to mean that “day-labor” was never a different, prioritized kind of service from standing and waiting in the first place, then Sonnet XIX does not redefine the act of standing and waiting. It must, if there is to be a collation, redefine the services to God performed in "day-labor." And if this is the case, then this collation can only bring the two together particularly by internalizing “day-labor," defining it as a "service” only in the sense that to perform earthly works is a form of bearing “His mild yoke” internally.

The consolation in Sonnet XIX is not an "anthem to resignation,” except in the particularly Protestant and radically individualistic sense that “Patience” here calls upon Milton’s resignation to another mode of understanding than the one which was wringing fear and self-pity from his pen. The counter-understanding-which is actually rather simple, and which is simply brought out by "Patience, to prevent that murmur" —is one which is hinged upon the internality of faith as being the essential life-blood of Christian service. The service of faith, for Milton, is not a faith that laboriously resigns to resignation, but the faith which in its resignation believes resignation to be unnecessary.

Milton is fully aware of the conceptual injunction that threatens to stand between the service provided to God in faith and the services provided to God by one's hands and feet, but he 
does not reconcile himself to God by failing to see how it is that the injunction is, vis $a$ vi his Protestant inclinations, an error of his own perception. Internally, and by declaring with God the identification of faith and works in one essential, internal activity, Milton sees the counterunderstanding which renders the injunction mute, and in seeing declares it. He believes it, and "it" is admittedly simple. The declaration of faith finally implies resignation only by precisely inverting it; resignation is not to embrace passivity, but to resign from the passivity which refuses to address the root cause of the anxieties that is buried in the psycho-volitional valences of consciousness itself. True resignation, on a Kierkegaardian reading of this poem, is to resign to actual consolation by way of the activity of faithfulness, which by the individual's permission alone can be allowed to reach, as choice and declaration, fully into the depth of introspection and reform it.

The consolation of Milton's Sonnet XIX is a strong hint toward the fact that Kierkegaard's dialectical narrowing of the distance between will and word by subjectifying Christian identity is something also at work in Milton's poetry. If so, then this intuition about the nature of internalized, but active service implicates even practices of reasoning in as much of an existential role as it does a more strictly knowledge-oriented role in the pursuance of disambiguation and certainty. The more Milton's understanding of reason is drawn out along this line, as well, the more apparent its existential valences become. Noam Reisner's study of “spiritual architectonics” and Milton’s “temple imagery,” for example, details how it is that reason, for Milton, is to cast away deceit; in doing so, Reisner traces Milton’s Platonic and Christian influences side by side as he discusses the separate, but paired roles of language and thought in Milton's incorporation of the Temple as a meaningful image in Paradise Regained. 
Ultimately, it is where the Christian and Platonic come together in an earlier Christian philosopher, Philo, that Reisner locates an apt analogy for Milton’s own understanding:

At the same time, as in each of us, reason has two forms, the outward of utterance and the inward of thought, he gave them each one of the two virtues as its special property; to utterance clear showing, to the thinking mind truth. For it is the duty of the thinking faculty to admit no falsehood, and of the language faculty to give free play to all that helps to shew facts clearly with the utmost exactness. ${ }^{95}$

"This Platonic encomium of truth," says Reisner, "and especially the notion that the rational principle 'has as its bounden duty to honour truth with absolute freedom from falsehood,' sounds recognizably Miltonic and reads like a page out of Milton’s memorable attack on censorship in Areopagitica as a direct assault on the abstract principles of Truth."96 The discussion of falsehood and truth here, though, as discussed in the context of a radically internalized activity of faith, is also reminiscent of Kierkegaard's own famous definition of truth as that which is "true for you." Guarding against the admittance of falsehood, existentially speaking, is not to guard constantly against uncertainty, but to guard internally against admitting any falsehoods that are actually false for you. It is the guard that truth maintains not solely against falsehood, but against the falsehoods of dishonesty.

A Kierkegaardian reading, here, replaces the intellectual valence so often riding under the banner of Reason, capital R, with a moral, reflexive valence more appropriate to the role of reason in an individualized sense: reasoning utilized pragmatically by an individual human in matters mundane and mystifying alike. And an individual emphasis must be internalized, perhaps

\footnotetext{
${ }^{95}$ Reisner, N. (2009), Spiritual Architectonics: Destroying and Rebuilding the Temple in Paradise Regained. Milton Quarterly, 43: 166-182. (P 172)

${ }^{96}$ Ibid.
} 
in Milton's case by way of connection to his understanding of service as the internalized resignation which, by resigning, resigns from resignation itself. Just as Milton’s “also” embraces a Protestant declaration of sola fida, and thus dismisses the disjunction between physically-active and physically-passive Christian service in favor the psychological activity already involved in "service," narrowly considered, Milton's impression of admitting the truth of the multitude simply because it is the truth of the multitude, and not because it is true for oneself, is Milton's denunciation of the Kierkegaardian "crowd.” As one of his most famous lines reads: "A man may be a heretic in the truth, and if he believe things only because his pastor says so, or the assembly so determines, without knowing other reason, though his belief be true, yet the very truth he holds becomes his heresie." ${ }^{97}$

Reisner's coupling of Philo and Milton above, though, also highlights something else: this is not the first time that Milton's understanding of Reason has been compared to the Platonic. Stanley Fish, discussed in Chapter One, begins his reading of Paradise Regained with a similar note on Milton’s so-called “Platonic Ideals,” borrowing that language from Russell Fraser's assault on Milton's intentional generalizations and universalities of language. ${ }^{98}$ It was for exactly this reason, in fact, that at the beginning of this chapter the connection between Kierkegaardian subjectivity and a concept of simplicity needed to be fully developed. The concept of simplicity is a better and more consistent way to analyze the purpose of reason (and narrated thought more generally) in Paradise Regained. Unlike "Platonic Ideals," which when related to Milton's poetic abstractions and claims of spiritual inspiration manage only to elevate the tension between knowing and unknowing, sound and silence, and activity and inactivity, a

\footnotetext{
${ }^{97}$ Milton, John, and Edward Arber. 1869. Areopagitica: a speech of Mr. John Milton for the liberty of unlicens'd printing, to the Parliament of England. London, 1644.

${ }^{98}$ Fish, 26.
} 
concept of simplicity allows for knowing to blossom naturally from prior unknowing, and for silence and sound to be wrapped up together in the processes of spiritual inspiration by which Milton claims to have written Paradise Regained.

An emphasis on simplicity is not unique to John Milton and Søren Kierkegaard as artists, either. In his famous "Statement to Marius de Zayas,” Pablo Picasso discussed something rather similar:

The idea of research has often made painting go astray, and made the artist lose himself in mental lucubrations. Perhaps this has been the principal fault of modern art. The spirit of research has poisoned those who have not fully understood all the positive and conclusive elements in modern art and has made them attempt to paint the invisible and, therefore, the unpaintable. ${ }^{99}$

With an eye toward the "invisible," which in this case is not the "silent" but the "ideal," the first thing that can be lost is the simple. Which means that perhaps Milton's intentions, if he is read through a Kierkegaardian lens, actually agree with Russel Fraser's when Fraser writes that "concreteness" and "specificity" are "the life-blood of poetry." ${ }^{100}$ And if that is the case, then to turn toward Platonic ideals, while it does follow a hint toward something else also working in Milton's poetry, is exactly the wrong response to it. Only an emphasis on simplicity, or on “positive and conclusive elements,” can properly classify Milton’s intentions as he approaches the paradoxical, the sublime, or the universal with his unique poetic style. ${ }^{101}$

From the beginning, this project has been bent toward uncovering the possibility that a characteristically Kierkegaardian authorial movement is transpiring beneath the surface of

\footnotetext{
${ }^{99}$ Pablo Picasso. "Statement to Marius de Zayas.” Columbia University. 1923. http://www.learn.columbia.edu/picmon/pdf/art_hum_reading_49.pdf.

${ }^{100}$ Fish, 25.

${ }^{101}$ Budick, 7-11.
} 
Paradise Regained. Among the final things to show, then, is that the "movement" which was “delineated uno tenor, in one breath,” in Kierkegaard’s authorship, a movement which unifies an otherwise splayed and fragmented authorial consciousness, may be the same movement which orients the unutterable, but counter-narrative (non-)silence behind the narrative "silence” of John Milton's Paradise Regained. That perplexing dissociation of Philosophy and Christianity noted by Price McMurray in Paradise Regained that stands against so much of Milton’s prosaic deliberations, and against his very incorporation of the "highest" Aristotelian themes in Paradise Regained itself, can only be made sense of by way of this one "movement," which is at home in Milton's prose and poetry alike. ${ }^{102}$

Milton’s own thought, like Kierkegaard’s three-stage dialectical performance, partakes in something like a play between the intellect and the imagination, between comprehension and expression, and within that space partakes in more than just one singular way. But it inevitably plays therein by way of the singular. Just as Kierkegaard's books are authorially characterized, so is Milton’s poetic speech. Milton even inserts himself as a character, qua inspired author, into the poetic universe he writes. More importantly, that same authorial voice is authoritatively overridden through this characterization of Spiritual inspiration-thus being overridden by both the historical Milton who wrote the lines and by the ambiguous inspiration attested to both in the writing of the lines and in the lines themselves.

Characterization also forms another bridge between Milton’s strategies and Kierkegaard's. Just as Kierkegaard's characterized authors are involved in the same overarching, indirect “movement” that is the domain of “S.K.," "author of the Kierkegaardian authors,” by

102 McMurray, 7. 
providing individual stages of reversal and reorientation, the movement that Stanley Fish locates as the unifying characterized passage of Paradise Regained repeats several times and through several characters. Stanley Fish described this “movement” in Milton’s work to be the pattern of expectation-disappointment-perplexity. We moved from there to show it as various stripes of a resignation to faith, or "silence," which is outlined in the text only inexplicitly, and which thus results for the reader as the pattern of expectation-disappointment-perplexity.

But because this patterned movement internal to Paradise Regained is a movement that is characteristically diversified, it is not a "movement" that is wholly unified: none of the separate characterized voices exhibit the same form and pace of the "movement" toward or through silence that all of them together imply. The Apostles have their worries, Mary hers, and Jesus His. Yet they are, of course, still all individually wrapped up in that broader movement, the "dialectical movement" which brings them all together out of the discrete and simple entities that each individually represents. The dialectics of Paradise Regained are not straightforward, but they are rooted in the straightforward, developing the indirect intuitions of pattern through the direct characterization of particular differences, across which commonalities point to something further.

Perhaps the best evidence of Milton's “indirect” concerns can be brought out with the help of an essay called "Poetry and Belief in Paradise Regained, to which is added, Samson Agonistes," a speech of Marshall Grossman's edited together posthumously and published in Studies in Philology. ${ }^{103}$ Grossman's achievement is the treatment of Paradise Regained and the added poem, Samson Agonistes, as two discrete poetic texts meant to be read side-by-side, just as

\footnotetext{
${ }^{103}$ Marshall Grossman. "Poetry and Belief in 'Paradise Regained, to Which Is Added, Samson Agonistes'." Studies In Philology, vol. 110, no. 2: 2013. p. 382.
} 
they were published. Through this combined reading, Grossman says, each is meant to be intuited in ways that alter the standard interpretations of both. Grossman's intentions and his conclusions bring out two distinct thoughts useful to the inquiry at hand:

Milton's setting of the poems as a dramatic confrontation of inward motions that are immediately acted out and those that are mediated by explicit reason engages, in a historical register, the appropriation of an identifiably Socinian style of argument and the peculiar Christology that follows from it and, in a formal register, the affirmation of poetry as a mimetic mediation of inward truth submitted to transcendental reason. I want, then, to think about the contrast between Samson's direct progress from "rousing motions" to action under the Law and Jesus's pause after his baptism by John to discover the nature of his messianic mission through a reasoned debate with Satan. The non-representation of Samson's thoughts in the one poem and the dialectical representation of Jesus's thought process in the other divide the old and new covenants according to whether or not divine motions are first mimetically articulated and submitted to reason. ${ }^{104}$

The first element that can be adopted from Grossman's work for the purposes at hand is the description of Paradise Regained itself. By setting Paradise Regained into a relationship with Samson Agonistes, Grossman brings out the dialectics of “inward motions” inherent to Christ's debate with Satan, as well as the ways in which Milton's poetic strategies imply a subjection of these "inward motions" to "transcendental reason." The second element, which concerns precisely how, on our Kierkegaardian terms, the transcendental ought to be understood in relation to Milton's poetry, is that on Grossman's provided terms (though in a way missed by Grossman himself), Milton's method of pursuing an understanding or expression of the relationship between "poetry and belief" is to publish two distinct, discrete, and themed ("frame of mind") poems which are meant to be read together.

${ }^{104}$ Grossman, 383. 
Poetical characterization in Milton, just like that of Kierkegaard's, must be understood as capturing a snapshot of this or that simple intuitive mode. Only by bringing such disparate modes so close to one another as to be read one after the other can the transcendental be seen for what it ought to be-not a direct mode of mimetically mediated engagement as given singularly by Paradise Regained, but by being mimetically mediated also requiring a rebound back into the realm of the indirect. This compounded incorporation of levels of transcendental reflexivity is an incorporation of the dialectics of Paradise Regained into a further disjunction requiring further dialectics. Such a model completes the Kierkegaardian turn discussed in Chapter Two, returning that exemplified link between silence and indirect communication given near-direct treatment in Paradise Regained back within the inescapable boundary of subjectivity that is Milton's radical individualism, because he refuses to say exactly how it is that Paradise Regained and Samson Agonistes cohere.

In his investigation of Paradise Regained, Grossman argues that "Milton implies that the covenant under which God reveals himself through his Law is superseded by reason itself, so that to pursue union with the divine and to reason become one and the same." ${ }^{105}$ As Grossman continues, "God is revealed as the totality of Reason, and reasoning is the path by which he is approached. In this scheme, poetry is a key mode for making visible that about which we reason.” Without a Kierkegaardian emphasis on what it is that "reason” here means, the trap that Grossman falls into is too readily available_-Grossman identifies Milton with the "Socinian theologians," using a parallel reading of Paradise Regained and Hebrews as evidence that “Milton’s reading of Hebrews, which is deeply informed by that of the Polish Socinian, Jan Crell...leads him to represent in these poems a soteriology of reason that anticipates (and in

${ }^{105}$ Grossman, 385. 
some ways enables) the Enlightenment." ${ }^{106}$ By this, Grossman means to say that the submission of "internal motions" to "transcendental reason” in John Milton's "Socinian” understanding makes of "the efficacy of poetry...a means of validating belief."107

Kierkegaard would likely have bristled at the idea that poetry could be used as "a means of validating belief.” If Milton's and Kierkegaard's radical individualisms are actually alike, as John S. Tanner argued in Anxiety in Eden, then perhaps Milton might have reacted the same way. ${ }^{108}$ For the validation of belief by way of a referral to a distinct structuration—even a poetic one-is exactly what Paradise Regained denies. Christ's “inward motions” throughout are subjected to "transcendental reason," but are immediately also then subjected to the inspiring Spirit. As are the “inward motions” of Milton’s, qua characterized author. Only the historical Milton's, as considered qua historical author, relationship to the inspirations of the Spirit that through poetry is subjected to "transcendental reason," and in this case only if an appropriate emphasis is placed on the "indirect" nature of the subjection therein. Even said in such a way, however, the emphasis still threatens misinterpretation: the spiritual inspirations that comprise the epic are not "subjected" to "transcendental reason," but imply and incorporate transcendental reasoning into an indirect method of understanding something that ultimately resides only within the category of a prior simplicity.

To uncover the simplicity that Milton's poetry communicates is to finally uncover the essential rejoinder between his work and Søren Kierkegaard’s. Simplicity highlights the irreducible internal movement productive of the fundamental tensions between activity and inactivity so characteristic of Milton’s “silence,” but through which little has been said regarding

\footnotetext{
${ }^{106}$ Grossman, 385.

${ }^{107}$ Grossman, 385.

${ }^{108}$ Tanner, 4.
} 
the links between (1) the peculiar agency of silence, (2) silence's abnegative valences traced all the way down to even the volition inherently tied up in consciousness itself, and (3) the external agential source (the "Spirit") necessary to make it possible that the activity of self-silencing might be less than a total negation of human freedom and human consciousness. By offering a way to relate to the world within the practices of subjectified-objective reasoning through which the individual, in a Kierkegaardian understanding, reflects, the "inspiring Spirit" of Paradise Regained invites Jesus' participation in the fate of Humanity without forcing him to surrender his essential subjectivity, and with it the necessity that he simply, and thus existentially, obey. The presence of the "Thou Spirit” does not just explain Milton’s inspirations; “Thou Spirit” also gives Jesus room to wonder what to do next, and by not knowing exemplify a service to God that is an unknowing obedience that, through obedience, becomes a knowing one.

In other words, well before the pinnacle moment the "Spirit leading" is leading a reflective Jesus in just such a way as to work earthly goings-on through him while he himself is preoccupied with hypotheticals and idealities, unsure as of yet where and in what way to "publish his God-like office now mature":

So they in Heav'n their Odes and Vigils tun'd:

Mean while the Son of God, who yet some days

Lodg'd in Bethabara where John baptiz'd, Musing and much revolving in his brest, How best the mighty work he might begin Of Saviour to mankind, and which way first Publish his God-like office now mature, One day forth walk'd alone, the Spirit leading; And his deep thoughts, the better to converse With solitude, till far from track of men, Thought following thought, and step by step led on, He entred now the bordering Desert wild, And with dark shades and rocks environ'd round, 
His holy Meditations thus persu'd. ${ }^{109}$

This early example becomes among the first instances of what Stanley Fish highlights as the reader-oriented pattern generating expectation-disappointment-perplexity. It is seen again, more overtly, in other passage Fish highlights. But it is also debated, about halfway through the poem in the beginning of the third book. And in this debate, Jesus gives a justification for his desert sufferings that seems, by his own explanation, to come hypothetically—-that is, through a "whatif?” Satan says to Jesus:

But to a Kingdom thou art born, ordain'd To sit upon thy Father David's Throne; By Mothers side thy Father, though thy right Be now in powerful hands, that will not part Easily from possession won with arms;

Judcea now and all the promis'd land

Reduc't a Province under Roman yoke, Obeys Tiberius; nor is always rul'd With temperate sway; oft have they violated The Temple, oft the Law with foul affronts, Abominations rather, as did once Antiochus: and think'st thou to regain Thy right by sitting still or thus retiring? ${ }^{110}$

To which Jesus responds:

All things are best fullfil'd in their due time, And time there is for all things, Truth hath said: If of my raign Prophetic Writ hath told, That it shall never end, so when begin The Father in his purpose hath decreed, He in whose hand all times and seasons roul. What if he hath decreed that I shall first Be try'd in humble state, and things adverse, By tribulations, injuries, insults, Contempts, and scorns, and snares, and violence, Suffering, abstaining, quietly expecting Without distrust or doubt, that he may know What I can suffer, how obey? who best Can suffer, best can do; best reign, who first

${ }^{109}$ PR, I.189 (italics mine).

${ }^{110}$ PR, III.162-164 
Well hath obey'd; just tryal e're I merit My exaltation without change or end. ${ }^{111}$

It may appear that Jesus is speaking tongue-in-cheek about not knowing what his future holds, but in a Kierkegaardian reading that interpretation would make little sense. For Jesus’ answer is not only set in the form of a hypothetical, the "What if he hath decreed," but also requires that he must, "quietly expecting, without distrust or doubt, that he may know what I can suffer, how obey?” The implication that Jesus can distrust or doubt at all, then, is that Jesus is by no means certain—he must trust because he does not yet know. Yet he is, narratively speaking, halfway through such an experience already; this is the beginning of Book Three, and Jesus has been in the desert, as lead by the Spirit, for some time. Why must Jesus not know? Why must he trust? In a Kierkegaardian reading, Milton must incorporate this transition from uncertainty into “publish’d office” because it represents the dialectical underpinnings of Milton's own protestant inclinations. The "deeds" in the desert discussed in Chapter One are the deeds that have been performed internally, through the psycho-spiritual development of Christ in the desert through which he not only proves himself, but becomes Himself. And where does he finally "become" Himself?

The final note of this project seemingly must, if it is to fall in line with traditional interpretations of Paradise Regained at all, render some semblance of sense to the pinnacle scene. But perhaps that is just the perception, and is also precisely what Milton himself refused to do. As Stanley Fish, Noam Reisner, Price McMurray, and Marshall Grossman all noted in their individual negotiations of the pinnacle scene, Christ's stand on the pinnacle is a stand in ambiguity—for some a stand intentionally written so as to remain ambiguous, for some to

${ }^{111}$ PR, III.182-197 
pointedly force disambiguation from the reader, but perhaps for no one (as far as I have found) to reconcile the reader to the fact that the pinnacle is no exceptional moment in relation to the counter-narrative undergirding the whole of the (negative) dramatic development outlined so well by Stanley Fish. The pinnacle asks and offers the reader no more than is asked and offered throughout: not just “believe,” or "be patient,” but more precisely “stop not believing,” and “stop not being patient.” Perhaps Jesus is both becoming and has become Himself throughout—is both silencing and silent.

If the dialectical inclusion of the activity of self-silencing and the activity of being silent together within any one of Christ's actions is read into the whole of Paradise Regained, then it is comparable to both Milton’s understanding of resignation to faith in "When I Consider How My Light is Spent” and Kierkegaard’s concept of silence in Christian Discourses. Radically internalized, resignation to belief or to patience is not a way to actually believe or exercise patience. To believe-through the interiorization of the Gospels that is the content in and through Kierkegaardian believes that "silence” becomes the activity—is to resign one step further: resigning in such a way that resignation itself becomes unnecessary. On Kierkegaard's terms, Milton’s “When I Consider How My Light is Spent,” like Paradise Regained, is an argument that the subject must not think twice about resignation as resignation, for such a second thought is itself a failure to resign. Quasi-resignation is not a silence, but the crying out which can give birth to silence.

Putting the concept of resignation itself to the test, Milton's total silence is not the partial silence of resignation to resignation, but is instead the incorporation of God's own agency as one's own; if the pinnacle holds more than a dramatic significance as the narrative introduction of the Aristotelian reversal that thus reintroduces the reader to the entire poem before it, then 
perhaps that added significance is in the unification of identity between Christ and God, opening up a paradise of renewed identity to mankind that is no more a loss of self than it is a resurrection of the birthplace of humanity, an "Eden raised in wast Wilderness," 112 and which makes of the ambiguous and indefinite "what else, then?” running counter to the negativity of self-silencing in Paradise Regained no longer something inscrutable, but something definite—and more than that, something simple.

${ }^{112}$ PR, I.7 


\section{Bibliography}

Barton, C. "They Also Perform the Duties of a Servant Who Only Remain Erect on Their Feet in a Specified Place in Readiness to Receive Orders: The Dynamics of Stasis in Sonnet XIX.” Milton Quarterly, 32: 109-122.

Bates, Catherine, “No Sin But Irony: Kierkegaard and Milton's Satan,” Literature and Theology 11, 1: 1997.

Budick, Sanford, The Dividing Muse: Images of Sacred Disjunction in Milton's Poetry (New Haven: Yale University Press, 1985).

Coleridge, Samuel Taylor, Biographia Literaria, ed. J. Shadowcross, 2 vols. (Oxford: Oxford University Press, 1907).

Coleridge, Samuel Taylor, Seven Lectures on Shakespeare and Milton by the Late S. T. Coleridge. Ed. John Payne Collier (London, 1856).

Collins, Anne, et al. Silver Blaze: and other stories. (Oxford: Macmillan Heinemann ELT, 2005).

Evans, C. Stephen, “The Role of Irony in Kierkegaard's Philosophical Fragments” in Kierkegaard on Faith and Self: Collected Essays (Texas: Baylor University Press, 2006).

Fish, Stanley, "Inaction and Silence: The Reader in Paradise Regained," in Calm of Mind: Tercentenary Essays on Paradise Regained and Samson Agonistes in Honor of John S. Diekhoff, ed. Joseph Wittreich, Jr. (Cleveland: Press of Case Western Reserve University, 1971).

Grossman, Marshall, "Poetry and Belief in 'Paradise Regained, to Which Is Added, Samson Agonistes'." Studies In Philology, vol. 110, no. 2: 2013.

Habbard, Christine, "Kierkegaard's Concept of Irony and the Philosophical Issue of the Beginning.” Kierkegaard Studies Yearbook 2009, 269-283.

Herman, Peter C., Destabilizing Milton: Paradise Lost and the Poetics of Incertitude (New York: Palgrave MacMillan, 2005).

Kant, Immanuel, Immanuel Kant's Critique of Pure Reason. Trans. Norman Kemp Smith. (Boston: Bedford, 1929).

Kierkegaard, Søren, Christian Discourses, trans. Walter Lowrie (New Jersey: Princeton University Press, 1971), 322.

Kierkegaard, Søren, For Self-Examination; Judge for Yourself! Trans. Edna and Howard Hong (New Jersey: Princeton University Press, 1990).

Kierkegaard, Søren, Kierkegaard’s Journals and Notebooks, ed. Niels Jørgen Cappelørn, Alastair Hannay, Bruce H. Kirmmse, David D. Possen, Joel D.S. Rasmussen, Vanessa Rumble. (New Jersey: Princeton University Press, 2008). 
Kierkegaard, Søren, Point of View on My Work as an Author. Trans. Walter Lowrie (New York: Harper and Row, 1962).

Kierkegaard, Søren, Stages on Life's Way. Trans. Walter Lowrie (New York: Schocken Books, 1967).

Kierkegaard, Søren, Upbuilding Discourses in Various Spirits. Trans. Edna and Howard Hong (New Jersey: Princeton University Press, 1993).

Lewalski, Barbara, “Milton: The Muses, the Prophets, the Spirit, the Prophetic Poetry,” Milton Studies 54: 2013.

Loncar, Samuel, "From Jena to Copenhagen: Kierkegaard's Relations to German Idealism and the Critique of Autonomy in The Sickness Unto Death." Religious Studies 47, no. 2 (2011): 201-216.

MacCulloch, Diarmaid, Silence: A Christian History. (New York: Penguin Group Inc., 2013).

McMurray, Price, “Aristotle on the Pinnacle: Paradise Regained and the Limits of Theory.” Milton Quarterly, 32: 7-14 (1998).

Milton, John, Areopagitica: a speech of Mr. John Milton for the liberty of unlicens'd printing, to the Parliament of England. London, 1644.

Milton, John, Milton's selected poetry and prose: authoritative texts, biblical sources, criticism. Ed. Jason Philip Rosenblatt. (New York: W.W. Norton \& Co., 2011).

Milton, John, Paradise Lost: And, Paradise Regained. (New York: Signet Classic, 2001).

Picasso, Pablo. “Statement to Marius de Zayas.” Columbia University. 1923. http://www.learn.columbia.edu/picmon/pdf/art_hum_reading_49.pdf.

Reisner, Noam, "Spiritual Architectonics: Destroying and Rebuilding the Temple in Paradise Regained.” Milton Quarterly, 43: 166-182 (2009).

Reisner, Noam, Milton and the Ineffable (New York: Oxford University Press, 2009).

Samson, David L., “Can Irony Enrich the Aesthetic Imagination: Why Kierkegaard’s explanation of Irony is Better than Richard Rorty’s.” Journal of Aesthetic Education 51, 2: 17-32.

Tanner, John S., Anxiety in Eden: A Kierkegaardian Reading of Paradise Lost (New York, New York: Oxford University Press, 1992).

Westfall, Joseph, "Kierkegaard and the Ingenious Creature: Authorial Unity and Co-Authorship in My Work as An Author.” Kierkegaard Studies Yearbook 2010, 267-287.

Williams, George Willis III, “Irony as the Birth of the 'Single Individual' and the Beginning of Politics.” Toronto Journal of Theology 28, no. 2 (2012). 